\title{
Ukraine's path towards democratisation. Interviews with Viktor Yushchenko, Mykola Riabchuk, Maria Tomak
}

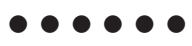

edited by

Iwona Reichardt and Paweł Kowal

[ Warszawa]

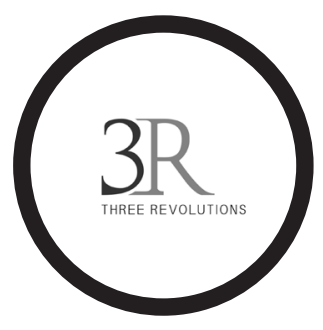

Wrocławski Rocznik Historii Mówionej Rocznik VII, 2017 ISSN 2084-0578 DOI: $10.26774 /$ wrhm.176

\section{Introduction $^{1}$}

Since the collapse of the Soviet Union in 1991, Ukrainians have been coming to Kyiv's main square (today called the Maidan Nezalezhnosti or Independence Square in English) to protest against the ruling elite and the dire situation in their country ${ }^{2}$. The first gathering took place in September 1990, one year before the collapse of the USSR ${ }^{3}$. The protest was initiated by a group of approximately 200 students who called for a hunger strike. Their demonstrations became later known as the Revolution on Granite. The name of this protest was a direct reference to the tents (approx. 50) which were set up on Kyiv's central square, where the protesters declared a "communism-free zone". Among the protest's participants were members of today's

1 This paper was written within the framework of the "3 Revolutions" project implemented by the College of Europe in Natolin.

$2 \quad$ See: O. Onuch, Mapping Mass Mobilization. Understanding Revolutionary Moments in Argentina and Ukraine, New York 2014; T. Kuzio, Democratic Revolution in Ukraine: From Kuchmagate to Orange Revolution, Oxford 2013; Revolution in Orange: The Origins of Ukraine's Democratic Breakthrough, ed. by A. Aslund, M. MacFaul, Washington 2006; A. Wilson, Ukraine's Orange Revolution, New Haven 2006; Ukraine's Euromaidan: Analyses of a Civil Revolution, ed. by D.R. Marples, F.V. Mills, Stuttgart-Hannover 2015.

3 K. Pryshchepa, Once a Protester, Always a Protester, "New Eastern Europe”, no. 1 (XXV) (2017), p. 11. 
344 Ukrainian elite: Oleh Tyahnybok (the leader of the Svoboda party), Svyatoslav Vakarchuk (Ukrainian rock singer), Vakhtang Kipiani (journalist and historian), Oksana Zabuzhko (writer) and Taras Prohasko (writer and journalist) ${ }^{4}$. Many of them came from Lviv, which since the 1970s served as an active centre of anti-Soviet intellectual movements ${ }^{5}$. The reaction of Kyiv residents and the Ukrainian society towards these protests was initially cautious (not many people even knew about the planned action), but gradually the general public showed their support and solidarity with the students. As a result of the demonstrations, the then prime minister, $\mathrm{Vi}$ taliy Masol, resigned and new elections were called.

The Revolution on Granite ended victoriously. It marked the first defeat of the communist regime and is regarded as a pivotal step in Ukraine's path towards independence. Nonetheless, the state of knowledge regarding this protest is still rather limited. Thus, while the general perception remains that it was one of the elements of the overall disintegration of the Soviet Union, there is less recognition that the 1990 student hunger strike was "a significant generational experience for the protesters, who were mostly born around 1970, during the times of Leonid Brezhnev, and grew up during the decline of the Soviet Union".

The Orange Revolution was the second revolution which took place in Ukraine after 1990. It started in November 2004 as a result of the second round of the presidential election, which was claimed to have been rigged to the advantage of Viktor Yanukovych and the disadvantage of Viktor Yushchenko ${ }^{7}$. As a result of the massive protests and international mediation, a revote was ordered by Ukraine's Supreme Court. It took place on 26 December 2004. The second run-off was declared "fair and free" and handed a victory to Yushchenko, who was sworn in as Ukraine's president on 23 January 2005.

$4 \quad$ P. Kowal, M. Wapiński, A Tale of Three Maidans, "New Eastern Europe", no. 2 (XI) (2014), p. 8.

5 M. Åberg, Paradox of Change: Soviet Modernization and Ethno-Linguistic Differentiation in Lviv, 1945-1989, "Harvard Ukrainian Studies", Vol. 24 (2000), p. 285-301.

$6 \quad$ P. Kowal, M. Wapiński, op. cit., p. 10.

7 A. Wilson, op. cit.; Revolution in Orange... 
Unlike the Revolution on Granite, the state of knowledge regarding the Orange Revolution was much greater from the very beginning. The demonstrations attracted wide international interest, both on the part of researchers, political analysts, and the media. However, both in Ukraine and abroad the interpretation of the 2004 revolution, and especially its consequences, has remained far from unequivocal. Generally put, while it is agreed that the revolution succeeded, it is often pointed out that the political elite that stood behind it failed ${ }^{8}$. It was proven to be impossible to turn Ukraine into a truly democratic state, which also affected the country's relations with external partners, including the European Union? ${ }^{9}$.

The Euromaidan was the last revolution that has so far taken place on the Maidan ${ }^{10}$. It started in November of 2013, and was initiated by a Facebook post authored by Kyiv journalist Mustafa Nayyem in reaction to President Viktor Yanukovych's refusal to sign the Association Agreement between Ukraine and the European Union ${ }^{11}$.

Initially, the gathering at the Maidan took the form of a peaceful students' demonstration which had some resemblance to earlier protests organised in Ukraine's capital. However, it soon turned out to be the bloodiest of the three revolutions. With an estimated 100 lives lost in Kyiv, and many more in the subsequent war in eastern parts of the country which began in the aftermath of the Kyiv revolution, the success of this political turnover is still difficult to determine. The street fights indeed ended in late February 2014, and a change in power in political structures took place (president Yanukovych fled Ukraine and new elections took place in May 2015). However, more than any other protest action, the Euromaidan revolution was expected to bring a qualitative change to Ukraine's public sphere. Led by thousands of volunteers and activists, the 2013-2014 revolution became regarded as a real civic movement, also called the Revolution of Dignity. The opposition politicians who participated in the revolution were there to represent the crowd more than to be its true leaders. In addition, while many of them were indeed elected in the post-Maidan elections

$8 \quad$ J. Forbig, Ukraine after the Orange Revolution, Washington 2005.

9 D.Ó. Beacháin, A. Polese, The Colour Revolutions in the Former Soviet Republics: Successes and Failures, London 2010.

10 A. Wilson, Ukraine Crisis. What it Means for the West, Yale University Press 2014.

11 M. Nayyem, Facebook, 24 November 2013. 
346 in May 2015 and became part of the new government, their actions (or lack thereof) continue to be controlled by the many participants of the protests who are now using new tools such as social media (Facebook and Twitter) to press politicians into continuing the changes that were demanded by the protesters and are now expected by western states and international organisations ${ }^{12}$.

"The Three Revolutions" project is an interdisciplinary research focusing on these events in Ukraine and which relies on the oral history method while collecting testimonies from their direct participants. The project has been carried out since November 2015 by the College of Europe (Natolin) in cooperation with the National University of Kyiv-Mohyla Academy, the Harvard University Ukrainian Research Institute, the School of Slavonic and East European Studies at University College London, Centre d'études des mondes russe, caucasien et centre-européen, the University of Alberta, and the Institute of Political Sciences at the Polish Academy of Sciences. The main goal of the project is to examine the issue of continuation in the process of social mobilization in Ukraine since the Revolution on Granite in 1990 until today.

As stated above, subsequent revolutionary events and social protests in Ukraine were connected by Kyiv's central location - Maidan Nezalezhnosti. However, it was not only the place and similarities in protest forms that solely determined the continuation between all three revolutionary events in modern Ukraine. This continuation can, as a matter of fact, be observed at three different levels. They include: 1) same location (Maidan), 2) similar protest forms (urban demonstrations and revolutionary actions) and 3) participation of the same people (as well as their relatives and friends) in all three protests. The latter inclines a transfer of knowledge on the methods and goals of protests which took place within families and smaller social groups. These observations have allowed us to formulate the following research hypothesis: The three most recent Ukrainian revolutions can be characterized by an inter-generational "learning by doing" process.

In the introductory phase of the project, when a decision was being made as to which research methods should be used to verify the above presented hypothesis, a seminar titled The Oral History of Ukrainian Revolutions was

12 R. Romaniuk, New Tools of the Revolution, "New Eastern Europe", no. 1 (XXV) (2017), p. 31 . 
held at the College of Europe in Natolin ${ }^{13}$. During this meeting, which took place on 19 February 2016, a discussion was undertaken in order to determine whether the oral history method was the most appropriate research method for this project and the results of other similar research projects which had been carried out in Central Europe and Ukraine which also used the oral history method were analysed ${ }^{14}$.

As a result of the discussions, it was decided that the biographic method used in oral history was the most promising for the project, considering that it would allow interviewees to freely present their entire political, social and family experiences. It was also clear to us that since the research objective required concentration on specific aspects of the interviewees' life experiences, this method had to be used in a wider framework, along with other sources ${ }^{15}$.

In the preparatory stage of the project, it seemed that the approach to oral history, which American scholar Michael Frisch called "more history"16, was the right choice for our research. It assumes that conducting oral history interviews allows for the expansion of existing knowledge of historical events. We opted for this approach aware of Frisch's own scepticism which he articulated while stating that this approach may lead to "mirroring conventional history"17. Aware of this possible drawback, we decided to opt for the "more history" approach, considering that in the context of recent events, especially in a country such as Ukraine, there is still a lack of other historical sources generated and thus interviews with direct participants hold a high cognitive value. This fact holds true not only for the revolutions that took place a few years ago, but also those that took place over a decade ago. In addition, it was quite clear to all members of our research team, regardless of our differing academic disciplines (among team members are

13 https://www.coleurope.eu/sites/default/files/uploads/event/seminarium_3r_19_ii_ eng.pdf (access: 11.04.2017).

14 http://www.3rnatolin.eu/events/ (access: 11.04.2017).

15 L. Shopes, What Oral History Is, and Isn't, [in:] Collecting and interpreting Qualitative Materials, ed. by N.K. Denzin, Y.S. Lincoln, Sage 2013, p. 121.

${ }_{16}$ See: M. Kurkowska-Budzan, Informator, świadek historii, narrator - kilka wątków epistemologicznych i etycznych oral history, „Wrocławski Rocznik Historii Mówionej", no. 1 (2011), p. 18.

17 M. Frisch, A Shared Authorityp. Essays on the Craft and Meaning on Oral and Public History, New York 1990, p. 187. 
sociologists, political scientists, and historians), that as researchers of contemporary events we cannot miss the unique opportunity to speak with the direct participants of events, even if our sources or the methods used call for caution.

The outcomes of the February 2016 seminar were later discussed with a team of academics who in their research focus on different angles of system transformation in Ukraine and the post-communist region overall. The results of these discussions were used to develop a multi-disciplinary research formula which inclines that the project outcomes will include: a) an analysis of archives' sources, including press materials and iconography of all three revolutions, b) an archive of oral history interviews with direct participants of all three events, c) organizing academic symposia which will allow for additional verification of facts obtained in historical sources. The first such seminar was held in Warsaw on 18 February - 1 March $2017^{18}$.

Consequently, collecting oral history interviews, even though a significant amount of time was allotted to this part of the project, has not been, in essence, the sole purpose of the research endeavour. As stated above, the project is not a classic example of research concentrated on applying one method. Yet, it is important to stress that high value has been placed on the method primarily because we are convinced that oral history allows an extraction of the so-called "human dimension" of the revolutionary events that are often described by historians and political scientists, but are also hard to get empirically tested in research. In the case of oral history, this extraction of emotions is possible thanks to the relationship that is established between the narrator and the interviewer. Such an experience was described, for example, by Michal Bosworth who pointed out the "directness" of oral history, which - in his view - decides on the higher value of this method over a classical review of sources ${ }^{19}$. Another researcher, Lutz Niethammer, stressed how the reconstruction of memory, especially by participants of events who - for numerous reasons - did not put their experiences in written form, significantly expands the historian's field of view ${ }^{20}$. Both these authors

18 http://www.3rnatolin.eu/events/ (access: 11.04.2017).

${ }_{19}$ M. Bosworth, Memory and the practice of oral history, [in:] Memory and history. Understanding memory as source and subject, ed. by J. Tumblety, Routlege 2013, p. 20.

$20 \quad$ L. Niethammer, Memory and History, Frankfurt am Main 2012, p. 37. 
have used oral history in their research, considering it an important source of knowledge and willingly stressing this fact ${ }^{21}$.

Franka Maubach, who analyzed research undertaken with the application of the oral history method in Germany in the second half of the 2oth century, also stressed the role of the researcher's approach to the interview $^{22}$. This is most visible when the researcher's academic background is taken into account as the method is clearly differently used by historians or political scientists as such as it is by sociologists or psychologists. Linda Shopes explains this by pointing out that the methods the researchers know from their own disciplines as well as their personal research experience is what determines the specific use of techniques ${ }^{23}$.

Adhering to the "more history" approach to oral history, we have developed specific rules of conduct that were expected of the interviewer carrying out the research in the framework of the project. Additionally, we prepared a list of participants to be interviewed. Their selection was made based on the desired categories and thematic areas. Subsequently, training was organized for interviewers in Kyiv and an academic conference was held in Warsaw summarizing the state of research into contemporary Ukraine in the context of the revolutionary events ${ }^{24}$. The outcomes of the conference reinforced our assumption that an application of the oral history method in the framework of our project should be treated as one of the constituting elements of the project, and thus we should provide researchers with the broadest possible opportunities to verify knowledge obtained through interviews by other sources.

Since a large part of the respondents-informers selected for our project were people who were politically or socially active (which is also one of the characteristics deciding on the unique nature of this research) the process of arranging interviews, or even their duration, had to be shortened, or

21 Interview with L. Niethammer, Oral History in Post-war Humanities West and East https://www.youtube.com/watch?v=Xk1lw5rdO8E (access: 6.04.2017).

22 F. Maubach, Świadek historii. Swobodne wspominanie a krytyka źródta historycznego - o ambiwalencji metody w zachodnioniemieckiej oral history około roku 1980 , „Wrocławski Rocznik Historii Mówionej”, no. 3 (2013), p. 45.

23 L. Shopes, Making Sense of Oral History, History Matters: The U.S. Survey Course on the Web, http://historymatters.gmu.edu/mse/oral.htm (access: 5.04.2017).

${ }_{24}$ https://www.coleurope.eu/sites/default/files/uploads/event/3r_conference_programme_final.pdf (access: 5.04.2017). 
significantly modified in many cases. Quite often, the interviewers were pushed to make such decisions because the respondent participated in only one of the events that we were researching. Despite this drawback, we were aware that for this research project (mainly because of the extraordinary historical circumstances that we were examining and which are still taking place, including the war in eastern Ukraine and its consequences), there are more benefits from the interviews which we have conducted and recorded than there were disadvantages and risks. That is why we were eager to make up for our shortcomings with other oral history interviews that were collected in Ukraine and available for researchers. These resources are also partially used in our project ${ }^{25}$.

The next issue to be accounted for is the diversity of narrators, or in our case informers as understood in the typology of Marta KurkowskaBudzan $^{26}$. This diversity is further reflected in the obtained material, best illustrated by two types of informers. The first group includes "ordinary" participants of the protests (the so-called participants "from below"). In this case, justification for conducting an interview is clear as the interview is probably the only possibility to access, for research purposes, the memory of a direct participant of historical events. Quite the opposite is true for the second group of respondents, namely politicians, in some cases those also holding high offices (former presidents, current parliamentarians, etc.) A series of limitations can be observed in regards to this group which were confirmed in our prior research experience and which include such challenges as: interviewees having a lack of time to meet and talk with the researchers, interviews taking place in uncomfortable, often excessively formal settings, difficulties with time allotment (politicians were unable to dedicate a set amount of time for an interview). These are typical situations faced by researchers who want to conduct oral history interviews with those who give interviews every day, and thus do not treat meetings with a researcher as something special ${ }^{27}$. Another important issue is that

25 See: G. Grinczenko, Historia mówiona na Ukrainie: ludzie, tematy, fakty, „Wrocławski Rocznik Historii Mówionej”, no. 3 (2013), p. 73-92.

26 M. Kurkowska-Budzan, op. cit., p. 9-34.

27 P. Kowal, Dlaczego doszło do Okragłego Stołu? Przyczyny zmian politycznych w Polsce w latach 1989-199o w opiniach polityków, aktywnych uczestników wydarzeń tego okresu, [in:] Komunizm. Ideologia, system, ludzie, ed. by T. Szarota, Warszawa 2001, p. 157. 
the researcher who uses oral history to conduct interviews with politicians is aware of the fact that this professional group is the least credible group of respondents in these kinds of research projects ${ }^{28}$.

Another issue to consider is the fact of misshaping stories by respondents. It takes place in the process of multiple recreations of historical events, which is discussed by Piotr and Hubert Francuz. In their text prepared for the Museum of the Warsaw Uprising, Francuz wrote:

The more often stories are brought up, the greater their durability (the principle rule of learning), but also (...) the bigger are their modifications. This is because autobiographic memories not only include "dry" information about an event, but also provide information about the way in which we personally experienced them (our emotions, goals, motivations, expectations, etc. at that time) ${ }^{29}$.

This "exploitation" of the overused autobiographic memory was quite visible in our research. We saw it the most in the transcripts of interviews with politicians. In many cases, they talked, especially when not interrupted, about the events that they had earlier discussed with other people - be it journalists or other researchers. Much could be written about the limitations of such interviews, however, it is also unwise to give them up entirely as quite often these politically active respondents hold important public positions for a very long time and it remains very uncertain when the moment comes that they will be able to make statements about past events that are not selective or aimed at self-promotion. The latter two tendencies are, unfortunately, quite common and thus researchers need to treat them with great caution.

At the current stage of research, we have conducted around 100 interviews in four languages: Ukrainian, Russian, Polish and English. The interviews have already been coded and are being prepared for publication and presentation to other researchers in an electronic database which will include both the recordings and transcripts (in the original language as well as translation into English).

28 M. Kurkowska-Budzan, op. cit., p. 15.

29 P. Francuz, H. Francuz, W barwach jesieni. Percepcja ekspozycji muzealnej przez osoby starsze, Warszawa 2016, expertise in P. Kowal's archives, p. 13. 
In this volume, we present the full transcripts of three selected interviews which are meant to represent each category of respondents: 1) a politician - interview with Viktor Yuschenko, 2) an activist - interview with Maria Tomak and 3) an opinion-maker - interview with Mykola Riabchuk. The interviews took place in Warsaw (Yushchenko), Kyiv (Tomak) and Kraków (Riabchuk). On average, they lasted one hour and each was recorded in one, uninterrupted session. All transcripts were translated into English with two interviews (Yushchenko and Tomak) translated from Ukrainian and one (Riabchuk) from Polish. In two cases (Yushchenko and Tomak) the language of the interview was the native language of the interviewees while in the case of the interview with Riabchuk it was the native language of the interviewer. The included transcripts were edited for this journal with the minimal possible intervention. Thus, only explicit repetition of words was eliminated and in some cases syntax was slightly modified.

Maria Tomak is a Ukrainian journalist and civic activist. She graduated from the Institute of Journalism at the National University of Kyiv. From 2007 until 2012, she worked for the Ukrainian newspaper "Аень" ("The Day"). She was involved in the Euromaidan since the very beginning as a volunteer with the Euromaidan SOS initiative. After the revolution, she became involved in the overall building of Ukraine's civil society, working for a non-profit organization called the "Center for Civil Liberties". In the interview, she presents her personal development path, her political engagement prior to the revolution as well as her direct participation in the Euromaidan. She also assesses the outcome of the Euromaidan from a two years perspective.

Mykola Riabchuk is a Ukrainian intellectual, journalist, literary critic, translator and writer. He has also worked as a political analyst, frequently cooperating with western media outlets where he was interpreting Ukraine's political developments. An author of numerous articles and books on Ukrainian history, he is widely recognised for his thesis of "two Ukraines" in which he presents the country's development from a post-colonial perspective. Although not an active participant in any of the revolutions (with the exception of one episode during the Revolution on Granite) Riabchuk was a close observer of all three protests, which he vividly explained through his writing to Western audiences. In the interview, Riabchuk shares his youth experience in Lviv which led him to become an anti-Soviet intellectual, writer and editor.

Viktor Yushchenko is a Ukrainian politician. He was the third President of Ukraine (January 2005 till February 2010). He won the presidency through the repeat runoff elections in which he had competed against 
Viktor Yanukovych. The latter's initial forging of the election in November 2004 became the main cause of the Orange Revolution, one in which Yushchenko became one of the key political leaders. Yushchenko failed to secure a run-off spot in 2010 , gaining only $5.5 \%$ of the vote. In 2012, in parliamentarian elections, he headed the "Our Ukraine" election list. However, his party failed to achieve parliamentary representation. In 2013 and 2014, Yushchenko supported the Euromaidan (initially acting as a moderator). After the revolution he supported the candidacy of Vitali Klitschko for president, while not participating in the presidential elections himself. In the interview, Yushchenko discusses the importance of the Revolution on Granite and the Euromaidan, however, he understandably presents his interpretation of the course of the Orange Revolution and its aftermath.

\section{Interview with Viktor Yushchenko ${ }^{30}$}

Kateryna Pryshchepa: We are going to talk about our project called the "Three Revolutions". We are trying to investigate the connections and consequences of the three largest protests that took place in Ukraine, which are probably not the biggest in terms of the number of participants, but in terms of their meaning for Ukrainian history. Based on our approach, such protests included the Revolution on Granite in 1990 ${ }^{31}$, which was a students' hunger strike. Thus, the first protest was the Revolution on Granite of 1990 , then the Orange Revolution ${ }^{32}$, and the third the Euromaidan of 2013-2014.33.

30 The interview with Viktor Yushchenko took place on 20 July 2016, conducted by Kateryna Pryshchepa, transcribed by Zofia Fijałkowska and translated to English by Yulia Pelepchuk.

31 The Revolution on Granite was the hunger strike organized by Ukrainian students in Kyiv in October 1990. For more see: http://mfa.gov.ua/en/news-feeds/foreignoffices-news/41110-25-ta-richnicya-studentsykoji-revolyuciji-na-graniti, http:/www. istpravda.com.ua/articles/2015/10/2/148579/ and http:/gazeta.dt.ua/socium/pershiymaydan-25-rokiv-revolyuciyi-na-graniti-_.html (access: 20.12.2016).

32 The Orange Revolution is the popular name for the political events that took place in Kyiv in 2004/2005 following the falsification of the results of the presidential elections. See: V. Paniotto, Ukraine: Presidential Elections 2004 and the Orange Revolution, "Kyiv International Institute of Sociology Report”, (2004), p. 1-27; M. Beissinger, Mechanisms of Maidan: The Structure of Contingency in the Making of the Orange Revolution, "Mobilization: An International Quarterly", no. 1 (16) (2011), p. 25-43.

33 The Euromaidan, also known as the Revolution of Dignity, is the common name for the events that took place in Ukraine between November 2013 and February 2014. 
It is very important for us to collect evidence from the direct participants of these events, about the events themselves, and also about their assessment of the meaning of those events for the history of Ukraine, and for everything that happened afterwards. Accordingly, we are very grateful that you agreed to talk with us, as it will be one of the most valuable pieces of evidence that we will receive in this project. I do not know how much time you can dedicate to the Revolution on Granite, but if you could tell me something about it, if you have some comments concerning it, we could dedicate several minutes to that first. As far as I understand, our time is limited, so we can pass onto the Orange Revolution directly and, perhaps, to the events of 2013-2014.

So, first a general question. How would you appraise the Granite Revolution and its consequences today, looking back ten years? Maybe you could tell us what was not achieved at that time? What was worth further struggle? Or how did the Granite Revolution influence the development of Ukraine immediately after it happened and now? How can you assess it from these perspectives?

Viktor Yushchenko: I believe that throughout the years that we are talking about - the last 25 years - there were two topical, serious challenges on both social and political levels. The first level related to the Revolution on Granite focused on whether there will be a Ukraine or not. This is a point of our formation, our modern formation, of course. It was when the politics of the country was represented by, I believe it will be fair enough to say, people related undoubtedly to the communist orbit, many of whom were engaged directly in pro-Moscow politics. And that is why the number of sovereignty issues included in that first referendum ${ }^{34}$ focused on Ukraine as a new union, it generated many topics for the agenda in which - in one way or another related to the question of whether you want a free, independent state to live in or you want a yoke around your neck and live where you are used to.

As a result of these events, President Yanukovych fled the country and new elections took place in May 2014. See: http://euromaidanpress.com/2016/o2/19/a-timeline-of-theeuromaidan-revolution/\#arvlbdata and E. Burgsdorff, The Euromaidan Revolution in Ukraine: Stages of the Maidan Movement and Why They Constitute Revolution, "Inquiries Journal", no. 2(7) (2015), p. 1-3; Ukraine's Euromaidan..., p. 1-344.

34 On 1 December 1991 Ukrainians voted in a referendum regarding the parliament's act of declaration of independence of Ukraine from the Soviet Union. See: http://www.ukrweekly.com/old/archive/1991/359102.shtml (access: 25.03.2017). 
I believe that the biggest contribution to this question was made by the Revolution on Granite. To a great extent, it laid the foundation for that answer, the mandate, which transformed into the national referendum where 91 per cent of Ukrainians said "yes" to the sovereign state ${ }^{35}$. This was the way to the political mandate. This defined how political power should act within the formation of the country's sovereignty. And owing to this mandate, to those events, the first president of Ukraine, Leonid Makarovych Kravchuk $^{36}$, spoke a lot about it. When he went to the Białowieża Forest ${ }^{37}$ for political negotiations, he did not have the right to step back. Even in yesterday's conversation ${ }^{38}$, during the debate, there was the question: "where is Ukraine's place?" Leonid Makarovych was repeating two phrases: "I don't know who Gorbachev is. I don't know what the Kremlin is" 39 . I believe that at this moment, our foundation was formed by this very event. The nation had a specific demand - owing to the first Revolution and basically that is why we came to such a political decision... the sovereignty of our nation, which we are talking about now.

KP: Could you recall what you were thinking about during those events? What impressions did you have about those students? Many people treated

35 C. Lapychak, Independence: Over 90\% Vote Yes in Referendum; Kravchuk Elected President of Ukraine, "The Ukrainian Weekly", no. 49 (LIX) (1991), p. 1-16.

36 Leonid Kravchuk is a Ukrainian politician who served as the first president of Ukraine (1991-1994). See: https://www.britannica.com/biography/Leonid-Kravchuk (access: 3.12.2016).

37 On 8 December 1991, representatives of Russia, Belarus and Ukraine met in the village of Viskule in the Białowieża Forest near the Polish border. Three politicians Boris Yeltsin (Russia), Stanislav Shushkevich (Belarus) and Leonid Kravchuk (Ukraine) negotiated terms which brought the end to the Soviet Union. See: The End of the Soviet Union: Stanislau Shushkevich's Eyewitness Account, "Demokratizatsiya", no. 3 (21) (2013), p. 315-337; http://fakty.ua/51373-leonid-kravchuk-quot-kogda-belovezhskiesoglasheniya-byli-podpisany-elcin-pozvonil-bushu-i-skazal-quot-gospodin-prezident-sovetskogo-soyuza-bolshe-net-quot (access: 3.12.2016).

38 Reference to a public conversation which took place at Warsaw University on 19 July 2016.

39 Reference to Mikhail Gorbachev, the last leader of the Soviet Union serving as the general secretary of the Communist Party of the Soviet Union. More on Kravchuk's speech at Warsaw University: https://charter97.org/ru/news/2016/7/20/214415/ (access: 3.12.2016). 
the protests perhaps with some caution... Did the students understand what they were doing? Did they understand what they wanted to achieve?

VY: As far as I can remember, thousands of Kyiv residents came out onto the Maidan - which wasn't yet called the Maidan during those times ${ }^{40}$. Thousands... It wasn't usually for the sake of solidarity, but very often there was a desire to see the protest with one's own eyes and then to draw one's own conclusions. I remember I was working not far away from the October Revolution Square, I was working at the USSR Gosbank $k^{41}$, in its Ukrainian office and of course, all of our bank employees, including me, often visited the Maidan. I believe that you are right. The attitude towards that protest was very cautious. Of course, we had no freedom at that time, we had no free mass media; there was no debate in the newspapers that would form the allies of this movement. But this gesture, I believe, was afterwards interpreted correctly by the absolute majority.

KP: So what could you say about the attitudes within your working group in regards to the protests? Did people support the protest or did they first want to see where it was going?

VY: In general, it was undoubtedly being supported. Maybe opinions varied on this issue, but I can generally recall that first discussion, how it got in there and how cautiously people approached the order of political work, protests, strikes... It was a sort of a gimmick... And, moreover, when it comes to the clear national positioning, it was still a question for many for very many people. It lasted for many months until we came to the December referendum ${ }^{42}$. But I repeat that it was that - it was the first song of our spring.

40 The Independence Square ("Maidan Nezalezhnosti") had different names in the past. The name prior to the USSR collapse was the October Revolution Square. See: https://www.interesniy.kiev.ua/za-vsyu-istoriyu-na-maydane-stoyalo-shest/ (access: 4.12.2016).

${ }_{41}$ Gosbank was the central bank of the Soviet Union. See: J. Johnson, Banking in Russia: Shadows of the Past, "Problems of Post-Communism", vol. 43 (3) (1996).

42 C. Lapychak, op. cit., p. 2. 

those events later?

VY: Well, we communicated a lot, you know, for the last 15 years he has been my political partner ${ }^{44}$. We frequently and regularly were in touch, also during these days. Of course, in some way we tackled this story, we discussed this practice and with those people who went through the first revolution. When we are talking about the Ukrainian liberation process, the Ukrainian formation of the last 25 years, one of the arguments that comes up, even during political campaigns, was always that... our path is sequential. Starting from the first question about our independence, the resignation of the Soviet government and up until the last revolution, it was a struggle for the future of Ukraine.

KP: With this question, I was trying to move on to the Orange Revolution. Do you think that the experience of the Revolution on Granite somehow impacted the way the Orange Revolution took place? Even this form of protest, when the tents appeared on Maidan Nezalezhnost $i^{45}$ - was it something spontaneous, in your view, or was this a direct experience being borrowed from the previous revolution?

VY: Obviously, in practice, a lot was used and borrowed from the political practice of the Revolution on Granite. I won't say that this was a mere repetition of something that someone read. But it was that experience

43 Vyacheslav Kyrylenko is a Ukrainian politician who is currently the deputy prime minister of Ukraine. He was an active participant of the Revolution on Granite in 1991. See: http://www.kmu.gov.ua/control/publish/article?art_id=247789233 (access: 5.12.2016).

44 Kyrylenko was Minister of Labour following the Orange Revolution in 2005 and later served as head of the Yushchenko's political party "Our Ukraine". See: https://www.ukrinform.ua/authors/vaceslav_kirilenko.html and http://www.pravda. com.ua/news/2009/12/21/4554208/ (access: 5.12.2016).

45 During both the Orange Revolution and the Revolution on Granite, protesters erected tents on the Maidan square in Kyiv. 
358 which Kyrylenko used for the organization of our resistance in $2004^{46}$. Of course, we were recollecting all the rational methods, gestures and steps that we had to take in order to successfully win these political challenges and competitions. We started with... it wasn't a challenge to put up tents. It was a challenge to get people to come onto the streets en masse on the next day when the falsified results were announced ${ }^{47}$. What scared the regime the most were the people. It was our only weapon - the rest was in their hands. This is the first thing. The second: obviously, we did not want to have even one drop of blood shed on the asphalt of the Maidan; it was the greatest argument for the authorities to resort to harsh activities. From the first moment when I encouraged people to come out to the Maidan, I was emphasizing that our action was peaceful; a peaceful mass resistance. No doubt this was soft power, but still it was power. And when hundreds of thousands of people were standing there, it would take special force to commit those crimes, as it was in 2013, for instance. That is why this was the second argument. I would say that it took the most time to get resolved because I would say that there were more than a few politically engaged people who viewed the political process of the Ukrainian formation as black and white. Black and white.

I had been asking a question, it was quite well-known, dozens of times: Why do we need it? ${ }^{48}$ Why do we need the government which does daily lists for pensions, salaries for serviceman and so on? Why do we need this paralysis? Why do we need this paralysis of the economy that we'll have to work with tomorrow and the day after tomorrow? Why should we be leading it to collapse, only to start developing it and then forever trying to fix it? Why do we need the administration of the president? Because there were such bizarre plans when the group of deputies came in, remained there, and other groups broke through and so on and so forth. Those in the authorities, I would say, were without a "territory" and this shaped their worldview. The

46 On Mr. Kyrylenko's recollections of the Revolution on Granite see: https:// www.ukrinform.ua/rubric-culture/1892345-kirilenko-rozpoviv-pro-svoyu-uchast-u-revolyutsiji-na-graniti.html (access: 5.12.2016).

47 Results were announced early on 22 November 2004 which announced that Viktor Yanukovych was ahead of Viktor Yushchenko despite exit polling which showed the opposite. See: A. Wilson, Ukraine's Orange Revolution, Yale University Press 2005.

${ }_{48}$ This refers to the protests on the Maidan. 
topic of the Ukrainian yellow and blue flag or the trident ${ }^{49}$, or the Ukrainian language, or the Ukrainian Church - they perceived many of these things differently than us. And this easily caused conflict with such people - even on a personal level. Because they are absolutely confident that they are fulfilling some sort of holy mission, having come from Berkut ${ }^{50}$, Simferopol ${ }^{51}$, Sevastopol ${ }^{52}$ or Donetsk ${ }^{53}$, they are doing some holy work.

And I was saying every day that I don't need the key to the presidential cabinet, which we will take by occupation. We have one task: to legitimately win the elections. The sense of victory is in it - to prevent conflict, especially a bloody one. Because all the rest devalues the purity of our victory. And that is why those projects aimed at taking over the government were almost impossible to achieve. And I disapproved again and said "I have been working in this cabinet in the post of prime minister for a year and a half already. Why do we need it now? What is the aim? What is the aim? We only incite an asymmetric provocation. We will fail. It will be a failure of the methods, not that we won't [be able to] occupy the building. It is not physically difficult to occupy a building. But from the point of view of the purity of our actions we would cast doubts. That's why taking into account the time and what happened in 2013, many mistakes were made, on different sides ${ }^{54}$. As what can justify the sacrifice of victims within the nation at the time of peace?

49 The trident is a national symbol of Ukraine.

5o Berkut was a group of Special Police Force managed by the Ukrainian Ministry of the Interior. See: http://www.euronews.com/2014/o2/26/ukraine-berkut-riot-policeto-be-disbanded (access: 8.12.2016).

51 Simferopol is a city on the Crimean peninsula of Ukraine. It is the capital city of the Crimean administration.

52 Sevastopol is a city on the Crimean peninsula of Ukraine and located on the southwestern coast of the peninsula on the Black Sea. It is home to the Russian Black Sea Fleet.

${ }_{53}$ Donetsk is a city in Eastern Ukraine. After the Euromaidan Revolution, separatist forces declared independence from Ukraine establishing the Donetsk People's Republic (DNR) with its seat in Donetsk. No country officially recognizes its independence. See: https://www.theguardian.com/world/2014/nov/o6/ukraine-rebel-peoplesrepublic-states (access: 25.03.2017).

${ }_{54}$ For more on Yushchenko's opinion on Euromaidan see: http://www.unian.ua/ politics/10264.04-yuschenko-poyasniv-chomu-ne-brav-uchasti-u-podiyah-evromaydanu.html and http://glavred.info/politika/yuschenko-evromaydan-delaet-to-ochem-naciya-mechtala-so-vremen-mazepy-264644.html (access: 6.12.2016). 
Taking all this into account, I would express appreciation for the political processes of 2004, 2005, 2009... You know, I would suggest considering this question in a broader sense. I don't like it, I would say, but if we start from this part of the political analysis, let's agree there is obviously no conflict between Western, Central and Eastern Ukraine on a human level. There are certain differences. We are living in one house. As Saint John Paul II said about two lungs, "we have to learn how to breathe with both lungs", using both left and right lung ${ }^{55}$. We know the history of the left-bank of Ukraine very well, we know about the Russification, how all Ukrainian praxis was destroyed there ${ }^{56}$. It means we understand the depth of the problem. The people are not to blame. They are only the victims of circumstances which they very often cannot even analyze profoundly. And very often, the people cannot see the right way for consolidation and unification. This is why dialogue exists. A national dialogue, we have to talk about this from morning till night. I am confident that when we communicate, we borrow from each other, or at least we receive facts - and that improves our worldview. And - this was one more task of the Maidan when the Orange Revolution adherents and the supporters of the democratic powers were gathering on the Maidan, an opposite Maidan was gathering at the distance of four kilometers at first, and then within the distance of only a few hundred meters. On the third day of resistance, we resorted to bringing food to their tents, because there was a dialogue. And they even often held their events on the European Square ${ }^{57}$. And it is literally 150-200 meters away from our Maidan. So basically, the people's diplomacy started working very actively. And this diplomacy is the most powerful. No matter that those people represent the Eastern part of our country, maybe we even speak different languages, but we are talking about the same things.

${ }_{55}$ Pope John Paul II used the analogy of two lungs in the human body to represent the Western and Eastern elements of Christianity. He used it on many occasions in the past. See: http://www.lpca.us/breathing\%2owith\%202\%2olungs.htm, http:/catholiccourier.com/commentary/father-mcbrien/church-must-breathewith-two-lungs/ and http://w2.vatican.va/content/john-paul-ii/en/encyclicals/documents/hf_jp-ii_enc_25051995_ut-unum-sint.html (access: 7.12.2016).

56 The Russification of Ukraine was a body of laws, decrees, and other actions undertaken by the Imperial Russian and later Soviet authorities to strengthen Russian national, political and linguistic positions in Ukraine. See: N. Chirovsky, Moscow's Russification of Ukraine: Papers and Articles, New York 1987, p. 1-124.

57 European Square in Kyiv is located at the intersection of Khreschatyk Street and Hrushevskiy Street, 400 meters from the Maidan Square. 
I believe that this was what the message of the Orange Revolution was about; that there are so many of us. Actually, there are tens of millions of us regardless of the geography of our country. In fact, we have to learn how to talk about the Ukrainian question and our converging today, and to overcome our weak national unity - the thing that exposes us to erosion. And this topic stands very high. It stands very high not only in respect of the Left- or Right-bank Ukraine issue, but also with a political purpose. Dear people, if we hold the policy of resistance as "either/or" we lose as Ukrainians. I think that even today people still perceive this topic with some difficulty - either Donbas wins, or Lviv wins ${ }^{58}$.

KP: You might recall that there were these postcards with three sorts of Ukraine, first introduced in the 2004 elections...

VY: On which I'm wearing a hat and explaining how to cleave our country and so on and so forth... I remember that. I remember I had an SS-uniform. This card was thrown into the political discussion. And I believe that the power of this revolution lied in the love which we expressed to each other, I mean on a human level, that the political construction - as he who had put up the resistance at stake lost, no matter if they say that democracy lead to cleavages, but I would say we had a third task: not only how to win the political process but, more importantly, how to embed our main doctrine into Ukrainian politics - how to turn the Ukrainian nation towards Europe, where we were one thousand years ago - the biggest European state? During the Cossack times, we wrote the first constitution in European history, even 90 years earlier than the Poles ${ }^{59}$. It all testified to the fact that the second problem - the problem of the political status of our development was at stake.

${ }_{58}$ This refers to divisions between the East (Donbas) and the West (Lviv) of Ukraine. See: A. Fournier, Mapping Identities: Russian Resistance to Linguistic Ukrainisation in Central and Eastern Ukraine, "Europe-Asia Studies", vol. 54, no. 3 (May, 2002), p. 41-433.

59 This is a reference to the Constitution written by Pylyp Orlyk, the Zaporozhian hetman in the 18th century. More on The Pylyp Orlyk Constitution see: O. Pritsak, The First Constitution of Ukraine (5 April 1710), "Harvard Ukrainian Studies", (22/1998), p. 471-496; http://www.lucorg.com/block.php/block_id/26 (access: 8.12.2016). 
I believe it was the basic political challenge of that time. I came with a clearly declared policy ${ }^{60}$. We advocated integrity to the collective security model, the economic model, the trade model, and our choice was European cooperation. It did not mean that we wanted to turn our backs on Russia. I stay deeply convinced today that when you take care of the wellness of your country you have to take advantage of the relations with the West, East, North or South. Geography has to work in the national interest of Ukraine - the same is for Poland or any other country. It is obvious that we tactically understand that there are present goals, strategic goals, and there are things that we put off, even while understanding that they are achievable. As such, the question of Russia, its future and our relations with it, has been put off. This is not because we do not need it, but because it is dangerous to cooperate with this Russia. This is not Russia which maintains order, joy, stability, and benefits, but does the opposite - it takes it away. And I would say that this position was achieved by us, we formulated such a policy, and travelled a difficult road over the last five years. And it's easier to recall it now than it was to act at the time. You know, there had been only one or two state visits since 200o. Either one or two. The Ukrainian government hadn't had negotiations with the outside world on a diplomatic level for more than five years. Many relations were lost, not only political ones. It was impossible to restore them within one year.

But let me be honest, whether you examine the economic situation of 20052009 , or you examine the social situation, or you conduct a financial or investment analysis, or the analysis of freedoms and its development, or you examine political relations with the world, I believe, that this five-year period was the best that we have had so far. Our economic growth was the highest in Europe ${ }^{61}$. We didn't fall lower than seven per cent. The national budget increased by three and

60 For more on Yushchenko and his pro-European strategy see: http://news.bbc. co.uk/2/hi/europe/4204149.stm (access: 7.12.2016) and O. Haran, M. Zolkina, Ukraine's Long Road to European Integration, "Ponars Eurasia”, no. 311 (2014).

${ }_{61}$ For more information on the economic growth of Ukraine during the Yuschenko presidency see: http://ua.korrespondent.net/business/economics/3684518-epokha-yuschenka-pryzabutyi-rozkvit-ekonomiky; http://gazeta.ua/articles/politics/_rokipravlinnya-prezidenta-uschenka-ce-najuspishnisha-pyatirichka-v-istoriyi-ukrayini/461955?mobile=true (access: 8.12.2016) and A. Aslund, The Economic Policy of Ukraine after the Orange Revolution, "Eurasian Geography and Economics", no. 5 (46) (2005), p. 327-353. 
a half times. Investments increased by seven times. Foreign exchange reserves, clear foreign exchange reserves increased by seven and a half times. Earlier today, I mentioned in one of the interviews that I received a country where pension was 50 hryvnias per month and I handed over a country where average pension was 497 hryvnias, pensions increased ten-fold and we began to buy 70 times more cars, household appliances, etc. These are all episodes which are very easily forgotten. We only remember the bad things. But the fact is that we changed such simple things as the quality of life in five years...

\section{$\mathrm{KP}$....the organization of our lives?}

VY: The organization of our lives. Well, maybe even this is not that important. What is important is that we came to a new level of freedom; to the next level of national improvement. We took it to the Declaration of National Unity ${ }^{62}$, which was signed by everyone except Tymoshenko ${ }^{63}$. Even the Communists signed it. Because, you know, turning back to the problem of unity, opposition is also a part of Ukraine. Even if it is a communist one. That is why it was important when, I don't accept, I condemn the communist idea, but those forces that were represented in the Ukrainian parliament and possess mandates of at least a part of the society, it is very important for them to learn how to speak a common language with the political forces which are a part of Ukraine. And it was very important for me that we signed a 27-point agenda and we found a common position. It included things that are separating us now: the topic of language, the Church, NATO, European integration, fiscal problems, the state budget - there were 27 points $^{64}$.

62 The Declaration of National Unity was a document which laid out key priorities for Ukraine in 2006 during a political stalemate which saw Viktor Yanukovych as the new prime minister of Ukraine. See: http://www.bbc.com/ukrainian/indepth/story/2005/o9/o50913_yushchenko_unity_declaration.shtml; http://www.rferl.org/a/ 1070302.html and http://www.rferl.org/a/1070301.html (access: 10.12.2016).

63 Yulia Tymoshenko is a Ukrainian politician and former prime minister (2004-2005; 2007-2010). She was imprisoned in October 2011 for abuse of power under the Yanukovych presidency and released only after Yanukovych fled Ukraine in February 2014. See: http://www.aljazeera.com/indepth/2014/o5/profile-yulia-tymoshenko-201452373836833511.html (access: 27.03.2017).

64 For more about the original text of the Unity Declaration see: http://zakon3.rada. gov.ua/laws/show/noo1010o-o6 (access: 10.12.2016). 
It was very important that every political force in the Ukrainian parliament, even ideologically different, could find common work, 27 statements, 27 steps which we signed - we were to work on them together. It was beautiful. And that is why I would say that for me, there is no doubt that the Orange Revolution essentially carried out its task. It put Ukraine on the European path clearly, accurately and, I would say, forever.

KP: Let us turn back to the events. You just mentioned that you managed to reach an understanding with the opposition, but during the protests how would you evaluate the role of the then-president Leonid Kuchma? ${ }^{65}$ How did he act in that situation? Or maybe European intermediaries helped find a way out of the conflict and resistance taking place at that time?

VY: I would say that the attitude to the political regime of Leonid Kuchma at the end of his term was very difficult. In fact, there were times when we basically did not leave the strike tents. We are talking about the strike of the tent town on Khreshchatyk Street ${ }^{66}$, which was blocking off traffic and was also blocking a significant part of political contacts of which the then political forces did not approve, and were in such a way working their will... In brief, for three or four years before 2004, Ukraine was like a "stormy boiler". I remember how many peace walks we organized along Khreshchatyk Street all the way to the Taras Shevchenko's monument - I emphasize, that it was a peaceful way - and despite being peaceful, it was also demonstrative, since it included a million people and that has to be considered ${ }^{67}$. The authorities were often choosing inappropriate methods of responding. Besides that, taking into account that the ministers were weak, especially those of

65 Leonid Kuchma is a Ukrainian politician who served as president of Ukraine (1994-2005). See: http://news.bbc.co.uk/1/hi/world/europe/2283925.stm (access: 9.12.2016); T. Kuzio, Ukraine Under Kuchma, Political Reform, Economic Transformation and Security Policy in the Independent Ukraine, London 1997.

${ }_{66}$ Khreshchatyk is one of the main streets in Kyiv. It leads to the Maidan Square.

67 For more information about Ukrainians protests for regime change prior to the Orange Revolution, the so-called Ukraine without Kuchma in 200o-2003, see: http:// nvdatabase.swarthmore.edu/content/ukrainians-protest-regime-change-ukraine-without-kuchma-200o-2003, https:/www.kyivpost.com/article/content/ukraine-politics/ukraine-without-kuchma-leader-yury-lutsenko-6683.html and http://news. bbc.co.uk/1/hi/world/europe/2277989.stm (access: 11.12.2016). 
internal affairs such as Bilokon ${ }^{68}$, who was dangerous for us as he was a mind-

less person. He could easily accept the anti-adjustment scenario. And I remember those debates in the parliament and I remember those reports of the minister of internal affairs and how we let him explain his hideous behavior to his children and his nation. It was a sort of political education that we had gone through, and when the revolution started I would say there were several points on which the subsequent directions of the process depended.

One such point was a session of the National Security and Defense Council $^{69}$ where the agenda included the choice of whether to suppress the Maidan or to accept the conflict as part of a democratic process. I know the details of that session. I think that a sober position was adopted by the president because he was not led by anyone. It was very important. We got to know everything in detail just a few minutes after the end of the session. We had several partners there. Second, the internal security troops had the decisive vote. Their head had this decisive vote. We were lucky to have such a sober person at the post of the head of the internal security office at the Ministry of Internal Affairs of Ukraine, who could accept such a basic compromise. My request was the following - knowing that the minister of internal affairs was a coward, that he would never adopt or issue an order to use force, I appealed to the staff with one request: as long as there is no written order from the ministry concerning the deployment of military actions, no forces should come into conflict with the people on the Maidan. Do not trust the words of the minister. It could serve as a pivotal point determining whether the events would be bloody or peaceful.

Of course, there were also other episodes with the "Desna"70 division and some other points, when international diplomats arrived... But I would

${ }_{68}$ Mykola Bilokon is a Ukrainian politician who served as the Minister of Internal Affairs of Ukraine (2003-2005). See: https://www.kyivpost.com/article/content/ ukraine-politics/kuchma-appoints-new-interior-minister-akhmetov-rum-1779o. html (access: 12.12.2016).

69 The Council on Security and Defence of Ukraine is a coordinative body on national security and defence under the President of Ukraine. See: http:/www.rnbo.gov.ua/ content/history.html (access: 12.12.2016).

70 The "Desna" division was a tank unit located outside Kyiv waiting for orders to move into the city during the Orange Revolution. See: http:/censor.net.ua/ news/155753/eksglava_sbu_smeshko_v_2004_pochti_tselaya_tankovaya_rota_byla_ gotova_po_prizyvu_yuschenko_dvinutsya (access: 13.12.2016). 
say that it sometimes took an opposite direction because I received calls from the presidents and the heads of European states concerning the inadmissible behavior, for example, when we are talking about the system of courts, or the system of the central government and so on. So it was obviously the daily process of the organization of that revolution. Of course, there was no plan elaborated for the next three months or anything like that, but what we did was well thought-out beforehand with clear determination of who does what and why. We avoided vain provocations which could have easily worked against the resistance, first locally between people, between the two camps, and then transferred to the government; and that is why I believe that many things in the history of revolution that have been investigated from different angles deserve to be clearly interpreted and fully understood.

KP: What was the role of people like Taras Stetskiv ${ }^{71}$, people who are called the commanders of the Maidan - were they intermediaries? Were they ruling on the spot, on the Maidan? What was their function?

VY: Very often those people were communicating every minute, every hour as needed to make the Maidan "live" - between two spots, for example, we were organizing a morning prayer, or a meeting, or saying what we were going to do that day, where were we going, or what goals we were trying to achieve and by going I mean not the whole Maidan, but the political representatives: what we were doing in the Supreme Court, what we were doing in the government. The president at the time was not going to work with us, it meant that he was not in Kyiv, but there were several contacts. Well, I had at least one contact with Kuchma outside of the city for the sake of one message (Ivan Stepanovych Plushch ${ }^{72}$ was with me then, a great politician) in order to give Maidan that correction, that development, that could lead us to a peaceful legislative resolution of the political conflict.

71 Taras Stetskiv is a Ukrainian politician and historian. During the Orange Revolution he led the blockade of the presidential administration building. See: http:// archive.is/5Wq3 (access: 25.03.2017).

72 Ivan Stepanovych Plushch is a Ukrainian politician who served as the 1st and 4th Speaker of the Ukrainian Parliament (1991-1994, 2000-2002) as well as the Secretary of the Security and Defense Council of Ukraine (2007). See: http://file.liga. net/person/398-ivan-plush.html (access: 12.12.2016). 
I remember it was the day when there was a meeting concerning the autonomy in Severodonetsk ${ }^{73}$, I asked the president if he was aware of it. I wanted to know whose idea it was and why Luzhkov ${ }^{74}$ was sitting in that meeting, why their regional councils were making decisions... decisions that created a dramatic demand for national unity. In short, this daily scenario had many factors and I believed that we were able to hold the main line chiefly due to good communication. Because I believe that the policies of the party leaders and party forces are interesting and useful when they can achieve their goals by means of political instruments.

KP: As was for the resolution method offered at the round table - the third one ${ }^{75}$ - was it the only optimal decision or did you have certain precaution concerning that formula of conflict resolution at that time? And who came up with this idea?

VY: It was a difficult price. If, you know, we are sitting in a hotel and thinking over what would happen if I agreed to the constitutional reforms which Kuchma offered for the sake of peace and to avoid bloodshed and subdue the resistance at a national level... ${ }^{76}$ On the one hand, I formulated my answer this way: I am an adherent of the theory that we have to move towards parliamentary democratization and the formation of a high-level of selfgovernment in our country. And the democracy, if you look at it in a historical perspective, it rejected the empires and the Czars, it moved to the constitutional Czars, then turned to a parliament, presidential and parliamentary, then parliamentary and then to the power of a community. As we can see in Switzerland, yes? Then it is clear that the direction of the political

${ }_{73}$ Severodonetsk is a city in the east of Ukraine which had attempted to declare independence during the Orange Revolution.

${ }_{74}$ Yury Luzhkov, is a Russian politician who served as the Mayor of Moscow (1992-2010). He is one of the founders of the ruling United Russia party. See: http:// www.bbc.com/news/world-europe-11425213 (access: 13.12.2016).

75 The third roundtable discussion took place on 6 December 2004. See: A. Wilson, Ukraine's Orange Revolution, p. 140.

76 The constitutional reforms put forward by Kuchma were meant to ease the political situation by allowing him to serve as president for another term. The reforms were voted down however in April 2004. See: http://www.pravda.com.ua/ news/2003/o3/6/2993052/ and http://ua.korrespondent.net/ukraine/246871-znakovi-podiyi-i-personi-2003-roku-v-ukrayini-vibir-korespondent-net (access: 14.12.2016). 
368 democratic process has to move in this direction. And Ukraine of 2004, I do remember this feeling, there were no political forces willing to live in the epoch of Kuchma when only one person mattered. To repeat the mistake particularly of the previous five years, when the country was under repression, when the Prosecutor General, the Sanitary Corps and the Security Services all became central political figures, when there were regular reprisals against national dissidents - nobody wanted to go back to this period.

That is why, I understood well that for the country's transitional period it was very important to have an operational model of the country's administration, which is given by presidential order. On the other hand, almost nobody liked the order, in which we have been living for the last ten years. Nobody wants to revert to it. This brings up the conflict between what you want in the future as president and, on the contrary, the practicality for regulation of deep national conflict. I chose the second road. I delegated the authority of the president to the prime minister ${ }^{77}$. Not to the parliament, but to the prime minister through the parliament, of course. Any other Ukrainian president did not work in such a manner, in which I worked from 2005 till 2009. It was like the authorization of the British Queen...

\section{KP: A little bit more...}

VY: A little bit more. A little bit more. But I would like to say, when we speak about political policy, which needs to be embedded and you do not have the right to affect it, beginning with regional administration - you cannot influence the head of the administration because it's not your candidate, it's a governmental candidate, concluding with how to name the conflict in Georgia - was it a Russian invasion? ${ }^{78}$ How was it decided by the parliament; which did not accept my position completely? Although, it is a component of the foreign policy of Ukraine ${ }^{79}$.

77 Reforms under Yushchenko took executive authority away from the president and gave it to the prime minister. See: Democratic Revolution in Ukraine: From Kuchmagate to Orange Revolution, ed. by T. Kuzio, New York 2009.

78 The Russo-Georgian War was a five day war which took place on August 7-12 2008. See: The Guns of August 2008: Russia's War in Georgia, ed. by E. Svante, S. Cornell, F. Starr, New York 2009.

79 For more on Ukraine's official stance in the Georgia-Russia conflict see: N. Shapovalova, The Positions of the Main Ukrainian Stakeholders on the RussiaGeorgia Conflict, "SIPU report", no. (2008), p. 1-7. 
There are many difficulties, but essentially, there is only one: I was deeply convinced that shedding blood was an unacceptable price and that indefinite conflict wasn't worth it; that I will be fighting for the practicability of parliament order for three to five years. It was not worth doing. I honestly, honestly, assumed an attitude that we needed to democratize the system of the political order in the country, even if a victory is almost in your hands, you voluntarily surrender your power and that is called democracy, understanding that you complicate the realization of your policies ten-fold. That is why I would say that these were the debates among all the Ukrainian sides. These were not the debates which were held by Kwaśniewski ${ }^{80}$ or Solana ${ }^{81}$, or anyone else. In general, I can say that the international observers did not formulate the settlement plan for us. No. We didn't need them for this reason. We knew how to settle this conflict. There was one thing, we didn't know - how the other side will act within the framework of the implementation of this road-map. And the failure of this plan of regulation, at least for one or two days, could lead us to what had happened in 2013 - to bloodshed. We needed experts to guide us and witness how we formulated a plan, beginning from constitutional reform and ending with how we mutually acknowledged court decisions; and the final step - the proclamation of a third round of elections ${ }^{82}$.

The Ukrainian Constitution, which we took as a basis for the conflict settlement, didn't give an answer to one important point: how to conduct the second round of elections. It was recognized as a forged round by the Supreme Court ${ }^{83}$. What do we do next? There is no way backward nor forward written in the Constitution. Each side considered that if it wasn't in the Constitution it meant we could not satisfactorily settle this conflict, and thus were going to be at war with each other for the next five years. Another side conversely believed that the government was illegitimate: we

so Aleksander Kwaśniewski is the former President of the Republic of Poland (1995-2005).

81 Javier Solana is a Spanish politician who was the Secretary General of NATO (1995-1999) and held key strategic posts in the European Union.

${ }_{82}$ V. Paniotto, Ukraine...; http://www.globalsecurity.org/military/world/ukraine/election-2004.htm (access: 16.12.2016).

${ }_{83}$ On 3 December 2015 the Supreme Court of Ukraine declared the results of the second round of the presidential elections invalid and called for a repeat of the vote. See: http://www.ecoi.net/local_link/8098/420120_de.html (access: 25.03.2017). 
370 don't declare this government; we aren't going to live with such a government. In three words, it was to be: an endless mutual conflict. And this is one of the testimonies of what a democracy is capable of. After three rounds, after three days of negotiations, and you know that the Maidan itself continued over several days, when the question was how to develop a strategy to end the crisis. That is to say we needed several days to write the settlement plan. That's all.

The continuation of the Maidan remained a control, if we did this, if we did that, what we had on our road-map. The Maidan itself was held out for several days to simply raise proper questions and to find a way to resolve it. So the power of the format was in finding national instruments of regulation and involving the high status of international actors to assist in the implementation of this plan. We acted strategically and quite quickly within the framework of the Constitution, and found a resolution in terms of the decision of the Supreme Court, which was accepted as legitimate by everyone.

KP: Briefly, could you assess what was wrong, what went wrong, what mistakes were made in 2013? You mentioned some of them. But you were trying to become an intermediary at the beginning of the protests in 2013...

VY: It was a different time - a different generation, although I would say I would have added a little more "dialogue". When we talk about the process of 2013, I believe that dialogue could have helped a lot in making the government act in one way or another. When there is no communication, the law of nature rules. This element is the worst scenario because nobody knows what your rival has prepared for you. That is first. In terms of politics I believe that the mistake of the Maidan was that it didn't grow into a political movement. And an absolutely new generation of politicians had to basically go into other political parties because of the law that was adopted after the Maidan. They didn't transfer the spirit, concept and strategy of the Maidan into the party system. So they joined other parties - they became ordinary. There is an interesting metaphor here: if you put two buckets of fresh cucumbers into a barrel of fully salty cucumbers, these new cucumbers become the same as the salty ones in 10 days. That's why the general idea of the Maidan was diminished. Also, they lost many interesting personalities who became the leaders of the Maidan and very good guides, with a sensible way of thinking and who had a vision of national develop- 
ment, they became subcontractors of those political monsters whose parties they had to join.

I believe that the adopted rule about the threshold of five per cent to enter the parliament was a fatal mistake of the Maidan movement ${ }^{84}$. There was no correction concerning the time for the creation of parties, because new parties weren't able to mobilize so quickly and such things should have been the demands of the Maidan, to eliminate this minimum threshold so that the spirit of the Maidan could have flourished. You know any party can hardly gain five per cent within three months. It takes time. The Maidan gave birth to those interesting, beautiful, and ambitious political forces. I still listen to many of those people with interest because they have

great rationality, great proper goals. But unfortunately this is a declaration; a declaration, which eventually turns into some demagogy because no one listens to him anymore. He doesn't implement his concepts anymore because he's no longer in the mechanism of forming the country's political decisions. I believe this was one more mistake and it is still perceptible today... Strictly speaking, the Maidan did not create a political force. And that is why we paid in great, great blood. We gave many pretexts and opportunities for political forces to weaken Ukraine.

KP: We hope there will be opportunities to amend this situation...

VY: I believe that the worst is over. We can say strategically that the exam which we have passed was the greatest exam, after which we can say that Ukraine is alive. The Ukrainian project is gathering momentum now. We have survived the most impudent and dishonorable Russian occupation, we have weakened the enemy, he looks like a clown now, he is ridiculous and incapable - and the situation is not simple, but on the other hand it is... it is a way forward. It is a way forward. And that is why the last years brought many things which were a part of my policies, but very often weren't considered. Starting with the topic of globalization, from our political movement to NATO and to the European Union, and all the internal issues which had

${ }_{84}$ In 2011 Ukraine passed a reform which created a threshold of five per cent in order to enter parliament. See: http://ukrainianweek.com/Politics/34145 (access: 25.03.2017). 
372 to do with the steps for consolidation, a national consolidation first, and how to become a firm nation, how to return to our mother tongue, as it is the core of our nationality, how to return to our native culture, how to be proud of our national remembrance, how to re-create a Ukrainian local Orthodox Church. In short, not only is it much more deeply important today, but it has also gained deeper acceptance by society. That is why, I believe, we went through all that - it was for a reason.

KP: Thank you very much for the time you have devoted to us.

VY: Thank you. 
Iwona Reichardt: Which part of Ukraine do you come from?

Mykola Riabchuk: Kyiv. From Kyiv.

IR: Thank you. I would like to ask my first question, still about the Soviet period $^{86}$. I would like to ask what shaped your thinking about the state, politics, and public affairs? Were these conversations in your home? Your contacts with the clergy? Was it your intellectual life at the university? What directed you, as a young man, towards who you are today and how you look at public affairs?

MR: Hmm... you know, in fact it was a process. Yes, normally an educational process is always, yeah, normally the educational process is always slow and I cannot say exactly what specifically formed me. I was of coursed raised in a, let's say normal, Lviv family, meaning my mother came from the Kharkiv oblast, my father was from Lutsk. Not fully Galician, but a Ukrainian family ${ }^{87}$. Quite diverse, because my mother was - nonetheless - a believing communist. Not orthodox, meaning she was critical towards this reality, but nonetheless, she believed even though she had experienced the Stalinist hunger, etc. ${ }^{88}$, but she believed in good Lenin ${ }^{89}$ and all these ideas.

85 Interview with Mykola Riabchuk, 30 May 2016, conducted, transcribed and translated by Iwona Reichardt).

${ }_{86}$ The Soviet period is estimated as the time from 1917-1991. In this interview, reference is to the late years of the period.

87 Galicia - region of east central Europe now divided between Poland and Ukraine. For more information about Galicia see: https://www.britannica.com/place/Galiciahistorical-region-Eastern-Europe and http://www.jewish-guide.pl/galicia/historyof-galicia (access: 16.12.2016).

${ }_{88}$ The Stalinist Hunger is a reference to the Great Famine (Holodomor) which was a Soviet policy directed at Ukrainian peasants (1932-1933). As a result, an estimated nine million people lost their lives. See: http://www.historylearningsite.co.uk/modern-world-history-1918-to-1980/russia-190o-to-1939/the-great-famine/ and http:// www.holodomorct.org/history.html (access: 17.12.2016).

89 Vladimir Lenin was the founder of the Russian Communist Party (Bolsheviks), inspirer and leader of the Bolshevik Revolution (1917) as well as the architect, builder, and first head (1917-1924) of the Soviet state. https://www.britannica.com/ biography/Vladimir-Lenin and http://www.biography.com/people/vladimir-lenin9379007 (access: 18.12.2016). 
374 My father, just the opposite. He was very skeptical, I would even say cynical in a sense. Always ridiculing. In my family, we did not talk much about politics, but my father would listen to the radio, western recordings, these different voices... And in these conversations I could see the irony quite early. Even when things were not said directly, there were some comments, some phrases - they were a bit sarcastic, especially when uttered by my father. My mother would often scold him as to why he talked in front of the children. Not why he talked at all, but why in front of the children, etc. So, I always had this certain skepticism. I also attended a Ukrainian school, so quite early with a group of other pupils, maybe already as teenagers, we were asking such questions as why Ukraine is not independent. The answer was very simple: if it could be, it would be. It was very specific. My acquaintance with Lviv students was quite possibly decisive for $\mathrm{me}^{90}$. With the family of Irina Koloneych ${ }^{91}$, and especially with Irina. She was in our school as a librarian. It was her who... who taught me somehow... she unveiled samizdat ${ }^{92}$, the underground literature, to me. So then, I started to read more serious things. Not only literature, but overall. And it was her who acquainted me with a group of my peers who were writing and thinking, and who turned out to be closer to me as they were of a similar age. This is when my activity became more focused and thought out - with this underground publishing, and so forth.

And then a change took place where I finally said goodbye to this idea of socialism with a human face ${ }^{93}$, which I probably had for my entire school years. Meaning, in my school age, I had this certain illusion that socialism

Lviv is an administrative center in western Ukraine with rich history and traditions. See: http://www.history.ucsb.edu/projects/holocaust/Resources/history_of_lviv.htm and http://www.lvivcenter.org/en/lia/ (access: 17.12.2016).

91 Person not found in historical sources, only mentioned during the interview.

92 Samizdat was the name of an underground press published during the Soviet period and directed against the authorities and the Soviet system. See: http://research. omicsgroup.org/index.php/Samizdat and https://www.britannica.com/technology/samizdat (access: 18.12.2016).

93 Socialism with a human face was a common expression used in regards to the socialist regime to contrast it with the Stalinist period of oppressive policies. See: https:// www.washingtonpost.com/archive/politics/1989/11/27/gorbachev-calls-for-socialismwith-a-human-face/eda17b7b-febe-4872-bdbd-d221f823b1b1/?utm_term=.013bo1674fed and https://www.nhd.org/sites/default/files/Stoneman_Senior_StanfordUniversityOnlineHighSchool_Wisconsin.compressed.pdf (access: 17.12.2016). 
is not bad, but... it was through my acquaintance with the samizdat that

I finally freed myself from this illusion. Hence, I can say that I became a real anti-Soviet man. Not a revolutionary, but a real one.

\section{IR: Was this during your studies?}

MR: Yes, that was in the 1970s. It ended very quickly as we were finally dismissed because of this samizdat. I was dismissed from the University of Technology $\mathrm{y}^{94}$ in 1973. I worked wherever, as... I could not find employment. I agreed to do anything not to get imprisoned. I somehow completed these studies at the University of Technology, and later started literary studies in Moscow ${ }^{95}$. I was also dismissed from there, but this time it was a more liberal dismissal, as the rector simply told me that he had some reports from the $\mathrm{KGB}^{96}$ and it would be better if I left on my own. So I left and finished during the perestroika ${ }^{97}$ period. I finished externally. So, I have two diplomas. I have not really made use of any of them, but I have them, and that would be it. And since the perestroika years, indeed... yes, that was the first coincidence as it was then when I arrived in Kyiv ${ }^{98}$. I got married and moved to Kyiv where my wife lives. I have made my home there since 1985 . I found a job there, as I was already publishing, a bit as a literary

${ }_{94}$ Lviv Politechnic University is the oldest technical university in Ukraine and Eastern Europe founded in 1816. See: http://www.lp.edu.ua/en/lp (access: 18.12.2016).

${ }_{95}$ Maxim Gorky Literature Institute is the Russian institution of higher education in Moscow founded in 1933. For more information about it see: http://litinstitut.ru/ (access: 17.12.2016).

96 KGB (Komitet Gosudarstvennoy Bezopasnosti), Committee for State Security, was the foreign intelligence and domestic security agency of the Soviet Union. http://www. topspysecrets.com/kgb-history.html and https://www.questia.com/library/history/european-history/russia-and-the-soviet-union/soviet-union/kgb (access: 19.12.2016).

${ }_{97}$ The Perestroika, or "restructuring" period, was a program instituted in the Soviet Union by Mikhail Gorbachev in the mid-1980s to restructure the Soviet economic and political policy seeking to bring the Soviet Union up to economic par with capitalistic countries. See: https:/www.britannica.com/place/Russia/The-Gorbachev-era-perestroika-and-glasnost and http://www.history.com/topics/cold-war/ perestroika-and-glasnost (access: 18.12.2016).

98 Kyiv is the capital of Ukraine. For more information about Kyiv see: http:// visitkyiv.com.ua/en/visiting_city_card/welcome_to_kyiv and http://www.bpci.kiev. ua/news/Conference_PGSIHS/ab_Kyiv.html (access: 18.12.2016). 
critic, meaning as a translator and literary critic. So, they accepted me to the monthly journal, "Vsesvit" that means "Universe", which is a similar magazine to Polish "Literatura na świecie"100. I was just an ordinary editor, as I was not a party member, so I was just rewriting others' texts. But gradually, as the perestroika was moving forward, I became the head of the literary critic division and in 1990 or 1991 the deputy editor in chief. And the events that you are asking about, meaning... that work in "Vsesvit" was such an inspiring event. The more I worked, that I lived in Kyiv, worked in publishing - I had some contacts already. So my whole energy was directed at the promotion of good texts and authors, both those that were closed and forbidden as well as those young ones whom I knew because I had this underground experience, I had the whole network, I knew a lot of young people, as we would be in touch, etc. So, I was there to push all this youth forward as a literary critic, and promote them. And not only through just some kind of reviews, but reviews for publishers. Because I also knew young people in publishing, not at very high levels, but during perestroika we could do a little bit...

\section{IR: Could you give me a few such names that you promoted back then?}

MR: There were probably a few dozen names. But from the most well-known ones, today I am of course the most proud of Andrychovych's ${ }^{101}$ book. But also, Viktor Neborak ${ }^{102}$, Aleksander Irvanets ${ }^{103}$, Aleksander Hrytsenko ${ }^{104}$,

${ }_{99}$ The monthly journal "Vsesvit" is the oldest Ukrainian journal of foreign literature founded in 1925. For more information about it see: http://www.vsesvit-journal.com/ pro-zhurnal/ (access: 19.12.2016).

100 A Polish literary monthly journal established in 1971. See: http://www.literaturanaswiecie.art.pl/historia.htm (access: 20.12.2016).

101 Yurii Andruchovych - renowned Ukrainian writer and poet. See: http://www.poetryclub.com.ua/metrs.php?id=258\&type=biogr, see: http://andruhovych.info/kritika-na-romani-yuriya-andruxovicha-rekreaci\%D1\%97-ta-moskoviadu/ and http://www.e-reading.club/book.php?book=100oo32 (access: 20.12.2016).

102 Viktor Neborak is a contemporary Ukrainian poet: http://www.poetryinternationalweb.net/pi/site/poet/item/7514/26/Viktor-Neborak (access: 20.12.2016).

103 Aleksander Irvanets is a contemporary Ukrainian poet, playwright and prose writer: see: http://www.ukrlit.vn.ua/biography/irvanec.html (access: 20.12.2016).

104 Aleksander Hrytsenko is a Ukrainian writer, intellectual and academic. See: http:// starylev.com.ua/old-lion/author/grycenko-oleksandr_(access: 20.12.2016). 
Petro Medianka ${ }^{105}$. All in all, there were many of them. And there were these different... But there was also the goal to defend, as a literary critic, well it was a bit weird at that time, but we had to defend those books that had already been published and they had to be defended from those Soviet dinosaurs, as they would like their reviews in the form of denunciations. So, I had to present an alternative voice and justify that these books were ok. I had to defend not only the authors, but also the publishers, from those party, those different... It was a bit stupid, because I had to be convincing that the book was not anti-Soviet, or decadent. That it was ok. A bit... Well, today I would not be publishing this, I would not republish these texts. They are... this activity was utilitarian in nature. But, overall, as an editor, I think, that as a critic and an editor, I have done certain things; in "Vsesvit" we published a lot of very good texts, including Kundera ${ }^{106}$, or Konwicki's ${ }^{107}$ Mata Apokalipsa, which was translated by Andruchovych. I commissioned this translation from him and it was translated from the samizdat edition in Poland. At that time there was no... I just got it from somebody in 1989. We could have done it as it already was perestroika. It was published in this grey...

IR: Yes, yes, these very small...

MR: Yeah. And very good. It was very good for both our readers and Andruchovych himself as he, his Moskoviada was written under the influence. You can tell that it was at the same time that he was translating Konwicki and writing his Moskoviada. Cleary some motifs are very similar. We were also publishing Miłosz's ${ }^{108}$ Captive Mind in fragments, actually starting with the Bal.... [problem with finding a correct Polish word - I.R.].

105 Petro Medianka is a Ukrainian actor and literary figure. See: http://litakcent. com/2011/11/29/petro-midjanka-\%E2\%80\%93-leksykohraf-centralnojevropejskoji-mahiji/ (access: 20.12.2016).

106 Milan Kundera is a widely recognized Czechoslovakian-born, France based writer see: http://www.famousauthors.org/milan-kundera (access: 21.12.2016).

107 Tadeusz Konwicki was a famous Polish writer and film director. See: http://culture. $\mathrm{pl} / \mathrm{pl} /$ tworca/tadeusz-konwicki_(access: 21.12.2016).

108 Czesław Miłosz was a renowned Polish poet, prose writer and diplomat. On his book Captive Mind see: http://biblioteka.kijowski.pl/milosz\%2oczeslaw/zniewolony.pdf and http://www.nobelprize.org/nobel_prizes/literature/laureates/198o/milosz-bio. html (access: 20.12.2016). 
MR: Balts. This last chapter. It was such a coincidence that it was at that time, in January of 1990... 1991 most likely, that the... Soviets attacked the TV centre in Vilnius ${ }^{109}$. People were murdered and so on. And I was then already the deputy editor-in-chief and managed to convince our boss that such an issue should be covered in our magazine, which was already in the printing house. And so, we added this last chapter, which was somewhere there prepared for later, but we just put it in like that, with an editorial introduction that we condemn violence and that this is a sign of our solidarity with the Lithuanians and so on.

So, I was quite involved in these different issues, things. And when the Revolution on Granite ${ }^{110}$ started to take place, for me and many other people, it was a certain surprise, even though different things were taking place. I wasn't really there. I did not participate. Maybe with one exception. There was such, a rather narrow group of students who were engaged in these issues. A general attitude of support. And I felt it that in the city... that the city liked them. That the majority of the city is, as if feels compassion towards them. There was no hostility. Kyiv was always friendly. That was the mood - maybe not such an anti-Soviet approach as in Lviv, but this scepticism towards the Soviets. And exactly if I remember correctly it was then that they started calling this square indepen... calling the square the Square of Independence, even though officially it was called the October Revolution square or something like that ${ }^{111}$. And it was then when they started to informally call it this way.

109 On 13 January 1991, 13 people were killed and more than 140 injured by the Soviet military in the capital of Lithuania as Moscow cracked down during independence demonstrations. For more see: http://news.bbc.co.uk/onthisday/hi/dates/stories/january/13/newsid_405900o/4059959.stm (access: 20.12.2016).

110 The Revolution on Granite was the hunger strike organized by Ukrainian students in Kyiv in October 1991. For more see: http://mfa.gov.ua/en/news-feeds/foreign-offices-news/41110-25-ta-richnicya-studentsykoji-revolyuciji-na-graniti, http://www.istpravda.com.ua/articles/2015/10/2/148579/ and http:/gazeta.dt.ua/socium/pershiy-maydan-25-rokiv-revolyuciyi-na-graniti-_.html (access: 20.12.2016).

11 The Independence Square ("Maidan Nezalezhnosti") had different names in the past. The last one was the October Revolution Square prior to the USSR collapse. See: https://www.interesniy.kiev.ua/za-vsyu-istoriyu-na-maydane-stoyalo-shest/, http:// www.mykiev.info/ru/dostoprimechatelnosti/rayony-i-ulitsy/kreschatik-i-maydan-nezalezhnosti (access: 4.12.2016). 
Meaning, it was a grassroots initiative and the Kyivians caught this slogan very quickly. The square got unofficially changed before it was officially renamed. There was one episode when I actually took part in the protest as on one day of the student hunger strike information spread that, most likely, the authorities want to use some kind of football match to get these football fans to provoke the students. And then the tension was really serious as we know that we don't have a good understanding of these football fan groups, that these are unpredictable people, that they can be easily manipulated, especially by the authorities, by the KGB. And this is when our intellectual groups, relatively young - we were young back then - we decided that we had to come to the Maidan. Not to defend, because we probably could not defend. When a few hundred thousand of these fans are marching forward, our small group of intellectuals does not have much chance to fight with them, but there was a thought that maybe our presence there, as nonetheless we were public figures - most of us were already known people, from publishing and other things. That this presence of ours will stop, maybe not the football fans, but the organisers of these counter-demonstrations. And that was the point. That is why we went there, there were maybe 20, maybe 30 of us. I remember that Oksana Zabuzhko ${ }^{112}$ was there and a few other well-known people. And the football fans, they always had such a tradition that they would walk - this Olympic Stadium ${ }^{113}$ is not far away, behind Besarabka - maybe one kilometre from the Maidan, or maybe even less, maybe less than one kilometre. They were marching in rows, hand in hand and were shouting these slogans of theirs, these jingles. They [the slogans] were stupid, but they were singing them. And the power was actually quite strong... that they are marching down this Khreshchatyk, keeping these iron rows and shouting something out, something like: Dynamo Champion $^{114}$. In Russian. This was such a general language: "Dynamo Champion, Dynamo Champion, Dynamo". Or they are swearing at the opponents. It depends. And they are approaching us and I remember that this was this feeling as if we were in front of military tanks which are coming at you and

112 Oksana Zabuzhko is a Ukrainian writer and poet. See: http://zabuzhko.com/ua/ (access: 21.12 .2016$)$.

113 The Olympic Stadium is a large stadium in the centre of Kyiv. See: http://nsc-olimpiyskiy.com.ua/en/stadium/ (access: 22.12.2016).

114 Dynamo Kyiv is a Ukrainian professional football club based in Kyiv and founded in 1927. See: http://www.fcdynamo.kiev.ua/en/ (access: 21.12.2016). 
you are sitting there in a cave and waiting. We were smoking cigarettes very nervously. But in fact, it was a revelation, there was such a relaxation when they approached the Maidan and Khreshchatyk ${ }^{115}$ was already opened to traffic. They reached the Maidan and suddenly somebody from their crowd shouted a popular slogan of that time: "Ukrainie wolu"116, meaning "Ukrainie swoboda", "Freedom for Ukraine". "Ukrainie wolu", in the perestroika times this slogan was getting very popular. Somebody shouted this out and others caught on. The football fans started to shout [laughter]. They are marching and shouting "Ukrainie wolu". And this indeed was such a... and this is when I felt that probably things will succeed, as it was really such... Especially after this tension, such a relaxation... It turned out that they are not enemies, but with us. There was this fraternal connection with the proletariat, so to say. And it was then that I had the feeling that we could succeed, that this will, when the fans are with us, then... The fans overall turned out to be a bit strange. Such was the case during this last [revolution] when they so unexpectedly supported these protesters in Kharkiv ${ }^{117}$ and in Odesa ${ }^{118}$, and in Odesa there was this tragedy... but they were also provoked, overall, as it was not a Ukrainian initiative. Anyway... so this would be it about my role in this first revolution. I was mainly a writer... so I wrote a lot. In different ways, for different publications. And this is when I started working with Polish publishers. I would do some stuff then... especially when this... newspaper was established... It did not exist for a long time but it was very good, very ambitious.... What was it its name... I don't remember, I'm drawing a blank now... I will remember later... this newspaper was meant to be competition for all others... What was his name...? this publisher...? He staged a musical and went to the US... What was his name...? Anyway, there was always a lot of work. The independence I experienced in Kyiv... I was then... I worked for "Vsevit" and I remember that

115 Khreshchatyk is one of the main streets in the centre of Kyiv which leads to the Maidan. See: http://www.encyclopediaofukraine.com/display.asp?linkpath=pages\% ${ }_{5} \mathrm{CK}$ \%5CH\% ${ }_{5} \mathrm{CKhreshchatyk.htm} \mathrm{(access:} \mathrm{21.12.2016).}$

116 Freedom for Ukraine. For more on this slogan see: https://day.kyiv.ua/ru/article/ tema-dnya-podrobnosti/podzabytyy-lozung (access: 21.12.2016).

117 Kharkiv is a city in northeastern Ukraine.

118 Odesa is a city in southeastern Ukraine. 
I was at the editorial office, at the time of the coup ${ }^{119}$. I was at work. I was always at work. I was not in the streets, with the exception of this Maidan...

IR: With the exception of the last one?

MR: No, the first one... In the last year. In the last one I was... As a visitor. Because my children actively participated in both. My wife, because we live nearby, so my wife would always go there and deliver food, or whatever. But my activity was rather limited to typing on the computer. I would sit, from morning till night, sometimes I would take foreigners there as there were always many journalists from abroad, for whom I simply was an interpreter, a stringer, in fact, I was taking them everywhere and helping them understand what this whole thing was all about and so on. But my main role was to write reports that they were not fascists, that these were... and so on.

IR: And how do you assess the impact of these revolutions, maybe one by one, on the future of Ukraine? Did this Revolution on Granite change anything? Did it influence later developments?

MR: That Revolution on Granite was, as I understand, important in a sense that it showed a certain ability for mobilization ${ }^{120}$. It showed that the authorities were ready for a compromise, that they do not kill, do not condemn... do not use force. And that was it... it stimulated for expanding this kind of activity. And at the same time, as I understand it from this perspective, I understand that this protest was used by one group of the nomenclature against another, meaning this more opportunistic group, led by Kravchuk $^{121}$, used it against these old hardliners to promote itself. Meaning

119 A reference to the 1991 August Soviet Coup which attempted to overthrow Mikhail Gorbachev. See: http://www.rferl.org/a/what-happened-to-the-august-1991-coup-plotters/27933729.html and http://www.history.com/this-day-in-history/coup-attempt-against-gorbachev-collapses (access: 21.12.2016).

120 N. Diuk, Youth as an Agent for Change: The Next Generation in Ukraine, "Demokratizatsiya", no. 2 (21) (2013), p. 179-196.

121 Leonid Kravchuk is a Ukrainian politician who served as the first president of Ukraine (1991-1994). See: C. Lapychak, op. cit.; http://www.globalsecurity.org/military/ world/ukraine/kravchuk.htm and https://www.britannica.com/biography/Leonid-Kravchuk (access: 22.12.2016). 
382 that they, in a way, made use of these students' demands, but they did not do the most important thing, meaning a change in the electoral system based on... competitive rules. This wasn't done. They removed this prime minister... Ok, they removed him, but so what as the division [recording unclear] stayed. And here, I would say that the students were somewhat naive. They did not have this experience to press for what was the most important. Meaning a compromise is ok, but it was not this kind of a compromise that was needed. It was important to introduce institutional changes, and that was not undertaken. So yes, I think that this revolution was important because even the fact that the more liberal nomenclature strengthened its position was ok. It was good that these old dinosaurs were removed, the ones of the Shcherbytsky ${ }^{122}$ kind. But overall, in my view, Ukraine was not ready for such fundamental changes then. The whole society was passive, Sovietised ${ }^{123}$. As a matter of fact, the elections, which - in my view - were quite free, showed it. In December 1991, maybe 30 per cent voted for the non-communist candidates. This was a reflection of the ability of this society to oppose, to some alternative thought. And the rest voted, as the authorities told them to. For some very small changes. So, in my view, this revolution was not finished... so to say... And...

\section{IR: And the Orange Revolution? ${ }^{124}$}

MR: The Orange Revolution... was not either... As we now know it did not succeed. It was immense. It was better... yeah, it was organized, on a large scale. Yes it was... [a revolution]. At that time, what is important, the opposition was institutionalized, and could lead and prepare. They were prepared,

122 Volodymyr Shcherbytsky was a Ukrainian and Soviet politician. He was a leader of the Communist Party of Ukraine (1972-1989). See: https://www.britannica.com/biography/Volodymyr-Shcherbytsky (access: 22.12.2016).

123 Sovietization is the adoption of a political system based on the model of soviets (workers' councils) or the adoption of a way of life and mentality modeled after the Soviet Union. See: http://ieg-ego.eu/en/threads/models-and-stereotypes/russification-sovietization (access: 22.12.2016).

124 The Orange Revolution is the popular name for the political events that took place in Kyiv in 2004/2005 following the falsification of the results of the presidential elections. See: V. Paniotto, op. cit.; M. Beissinger, op. cit.; https://www.wilsoncenter.org/article/ the-orange-revolution-and-the-maidan-parliament (accessed: 23.12.2016). 
everybody knew that there will be pacifications... and the protests were prepared, peaceful. So in this sense, everything turned out really well, without violence. It was possible to negotiate new elections. Only... again the society turned out to be unexperienced, and did not force the authorities to work as they should... right?

IR: You said that you were often explaining these events to foreign observers. When it comes to the Orange Revolution foreign actors were quite involved. How do you assess their involvement?

MR: Yes, I think it was very good and thanks to it, in my view, it was possible to avoid violence. I think that they played an important role, as we don't know what would have happened without these international mediations. At that time, I was actually in Kyiv, because during the Euromaidan ${ }^{125}$ I was commuting between Vienna, meaning between Europe and Kyiv, while during the Orange Revolution I stayed in Kyiv. Meaning, I... as we live in the center, everything was right in front of my eyes. I would go there every day, take somebody along. And every day we had a lot of people in our flat. Imagine a flat that was full. Some people were coming in, others leaving. I had the impression that all of Kyiv, maybe not the whole city, but the center, functioned in this way. Meaning, people were accepting foreigners. Well, sometimes these were people whom my children knew. Sometimes, people from the province, who were recommended by somebody. But sometimes there were complete strangers. I remember, as if it was today, these boys from Zhytomyr ${ }^{126}$. Young boys. They were students of some kind of agricultural university. It is difficult to imagine such a situation normally, that you just give your keys to someone that you don't know. And our flat was a sleeping area and a washing service and a public kitchen, and everything

125 The Euromaidan, also known as the Revolution of Dignity, is the common name for the events that took place in Ukraine between November 2013 and February 2014. As a result of the events, president Yanukovych fled the country and new elections took place in May 2014. See: http://euromaidanpress.com/2016/o2/19/a-timeline-of-the-euromaidan-revolution/\#arvlbdata and E. Burgsdorff, op. cit.; Ukraine's Euromaidan...

126 Zhytomyr is a city in the north of the western half of Ukraine. For more information about it see: https://discover-ukraine.info/index/central-ukraine/zhytomyr (access: 22.12.2016). 
384 else it could be. Back then, it was such an exciting time. Such adrenaline. I had to get to my computer, because I would start everyday with writing for all kinds of western publications, and if not for publications then to my friends-journalists, to different acquaintances, and explain to them what was going on. And I had to get over these bodies on the floor, as they were sleeping everywhere... on these mats and carpets... just to reach to the table.

[Break in the recording - technical problem]

So what's left is the last revolution. In this one, I participated the least as I was outside Kyiv. It surprised me in... Norway as I was there at a Eurozine $^{127}$ meeting...

\section{IR: I remember that...}

MR: Exactly. There we were following what was going on. And after that I returned to Vienna, and later went to Kyiv. And I was there till more or less our Christmas Eve, meaning till January 7 [2014]. And then I went to Vienna again. After these events, this violence, these fights, I also came back, and stayed till more or less mid-February. So, it was kind of a strange situation that whenever I left, the fighting would start. And when I was in Kyiv, it was relatively calm. Anyway... I did not participate in these street events... Simply, as an old man, and secondly as a person who then had something different to do. And there was a lot of work because I, in that year... I did not count exactly, but for sure I had over one hundred publications... Interviews... all of that. And also after this revolution it was important to go to foreign countries, capitals, and explain what was going on and mobilize the public opinion. The record was in Paris when on one day, together with Marynovych ${ }^{128}$, we had four different meetings. In the morning we were at the French Ministry of Foreign Affairs - it was a closed expert

127 Eurozine is an international network of cultural magazines and publications. See: www.eurozine.com (access: 21.12.2016).

128 Myroslaw Marynovych is the vice-rector of the Ukrainian Catholic University in Lviv, co-founder of Amnesty International Ukraine, and a founding member of the Ukrainian Helsinki Group. See: http://ucu.edu.ua/eng/about/administration/myroslav-marynovych/ (access: 22.12.2016). 
seminar, later at the Schumann Foundation ${ }^{129}$, later at CERI $^{130}$, a panel, and a big lecture in the evening (a lot of people came, I did not even expect it) at the university. And later to Brussels, where it was the same. And then I understood the problem of those football players who even though they travel a lot, they do not see much apart from hotels and stadiums. No pleasure from these travels.

IR: And this explaining of this last revolution was it different than explaining the Orange Revolution? You said that this time you had to convince...

MR: It was different for many different reasons. It was not prepared, of course, unlike the Orange one. There were no leaders. It means that they had to use those politicians who were there. I understand that this is a serious dilemma, as there is a protest and there needs to be somebody to negotiate with. And when negotiating, there must be a representative of this and it is difficult to find leaders in such a mass of people. If there was somebody charismatic, but as there was no one, they used those politicians who were representatives of the political opposition. And that also had negative effects. But, there was a moment of escalation of violence, which did not happen during the Orange Revolution. It is difficult to say whether it was thanks to Yanukovych ${ }^{131}$ or whether there were also some Moscow forces, or pro-Moscow. Some kind of agent work. For the moment we don't know as these events were very strange. It is difficult to explain. In any case, the course of events was completely different than in 2004. But, I think that everything can turn good in a sense that now as I see it - the society is more educated, experienced in a sense that it does not trust politicians as it used to. At that time, it had more illusions, as it seemed that we finally chose our people: Yushchenko. Yushchenko, Yushchenko, the whole Maidan was shouting. Yushchenko, Yushchenko. Yushchenko. And Yushchenko was chosen. Now they don't trust and they don't have these

129 The Robert Schuman Foundation is a Christian Democratic think tank affiliated with the European People's Party group in the European Parliament.

130 CERI (Centre de Reserches Internationales - Sciences Po) is a French research centre that concentrates on both international/transnational relations and regional studies. See: http://www.sciencespo.fr/ceri/en (access: 22.12.2016).

131 Victor Yanukovych, Ukrainian politician who served as president of Ukraine (2010-2014). More on Yanukovych see: https://www.britannica.com/biography/ Viktor-Yanukovych (access: 16.12.2016). 
386 illusions. They know that they still need to guard, that politicians are not perfect. They simply cannot be perfect $a$ priori. Man is not perfect. They have to be looked at and forced to act... and they are forcing them. They don't want it very much, but from what I can see they are doing it - when forced to. There is no doubt about it. They are doing it, even though they don't want to. But society is pressing them, the West demands, controls... and they, how to say, more slowly, but are going forward. Anyway, I cannot see anything that would be moving the country backwards.

IR: And while looking at these three revolutions, do you think that this is some kind of typical Ukrainian characteristic of political change? Or do they show traces of a more European tradition?

MR: I think that, of course, Ukraine is nonetheless a part of Europe. I think that this is a part of Europe, well at least the one that was one part of the Polish Republic ${ }^{132}$ and this part has these freedom traditions, meaning freedom has always been valued here. This is how I understand it. This is maybe even a medieval tradition, yes, from this Republic. What were the Cossacks ${ }^{133}$ talking about: about these golden freedoms. Of course, I understand that they were talking about tier freedoms. For themselves these freedoms, but every person can understand this freedom for himself. Freedom has always been a value. To a much greater extent than somewhere there further in the East, as I assume. This idealization was greater here. And also, the concept of dignity. Here, I can see the European heritage. Marginal, probably. I know that this is a margin of this European world, but Ukraine - it seems to me - unlike Russia has never had such respect towards authorities. Such respect with anointing. No matter what authorities, they are always received here with skepticism, but especially corrupt authorities. These politicians raise no respect. They get delegalized. That is why, Yanukovych, to maintain

132 The First Polish Republic or the Polish-Lithuanian Commonwealth was the name of the state which covered Polish, Lithuanian as well as parts of Ukrainian lands until the late 18 th century. See: N. Davies, God's Playground. A History of Poland, Vol. 1: The Origins to 1795, Vol. 2: 1795 to the Present, Oxford 2003.

133 S. Plokhy, The Cossacks and Religion in Early Modern Ukraine, Oxford 2001; A. Basilevsky, Early Ukraine: A Military and Social History to the Mid-19 ${ }^{\text {th }}$ Century, Jefferson 2016; http://www.encyclopediaofukraine.com/display.asp?linkpath=pages\% ${ }_{5} \mathrm{CC}$ \%5CO\%5CCossacks.htm (access: 23.12.2016). 
power, had to mobilize his whole Soviet electorate. He had to artificially spin up this, this language confrontation, which is complete fiction, and which has been prepared by Manafort ${ }^{134}$ and all these technocrats, those sons of bitches, I am sorry. I understand why it was rational, because this electorate is passive. It has to be forced to vote. It is numerous. And this number needs to get transformed into votes, which is why it was necessary that they at least went to vote. Hence, in this way the goal was reached. Yanukovych became president. But the price of this is the breaking up of the state. Russian intervention, as Russia has very skillfully used this whole propaganda. Aha, you are saying that we need to protect the Russian minority, yes, of course they are here. They themselves, say that they are suffering. You are talking about the fascists. Of course, the fascists are here. It is not Putin ${ }^{135}$ who came up with that. Only Yanukovych's propaganda; Putin, in turn, knew how to spin it on a global scale. That's it. Thus... The Ukrainians, nonetheless, as I understand it, have been - for years - used to certain freedoms. Ukraine has, indeed, never been an authoritarian state. It has always been a democracy, just not as liberal as let's say...

IR: Oh, this is a fashionable concept these days...

MR: Without the rule of law. Without a strict rule of law. But a concept of freedom has always been here and this pluralism has always been here. No matter what kind. And it is always closer to democracy from pluralism than it is from authoritarian rule. Hence, in this sense it seems to me that all these revolutions were unavoidable, and necessary. Please note that it is difficult to talk about the first one, as I even have doubts whether we could treat it as a revolution or not, however the Orange one (as it was unquestionably a revolution) and the Revolution of Dignity, in both cases it was caused by some kind of brutal breaking of rules by the authorities. They broke some kind of their own rules. And this causes shock and disapproval.

134 Paul Manafort is an American lobbyist and political consultant who worked for Viktor Yanukovych. See: https://www.washingtonpost.com/news/the-fix/wp/2016/o8/19/ paul-manaforts-complicated-ties-to-ukraine-explained/?utm_term=.3cca17do6345 and http://fortune.com/2016/o8/15/5-things-you-need-to-know-about-paul-manafort/ (access: 23.12.2016).

135 Vladimir Putin is a Russian politician and president of the Russian Federation (2000-2008; 2012-present). 
388 Not some kind of higher prices, or something like this. Prices always go up. This could cause some protests of separate groups, but not mobilization of the entire society. A mobilized society is one that has been hurt, seriously hurt. Morally hurt, not by money or something like that. But by treatment. The same took place in Moscow when Putin did this gambit with Medve$\operatorname{dev}^{136}$. This was also making people feel stupid. People, at least some, felt like idiots. What, did they think we are crazy? Something like this was also in Ukraine when these elections were forged by Yanukovych, by Kuchma ${ }^{137}$ with Yanukovych. And also when the decision to withdraw from this association agreement ${ }^{138}$ was made. That is why, I do not believe in the talks that say that there will be a third, fourth, fifth Maidan.... This is not so simple. Maybe. I cannot say that it will not take place at all. But it will not take place just because somebody wants it to take place. That somebody did not like Poroshenko ${ }^{139}$ or the authorities. The authorities need to do something that will really affect people's...

\section{IR: Dignity?}

MR: Absolutely. As otherwise people will complain. They will, but as long as there is a possibility to vote and by voting... There is a good American saying: when there are belts, there will be bullets. And for the moment, in Ukraine it is still possible to work with belts, and not bullets. But I would not exclude that one day there will be such a need. The country is prepared

136 Dmitry Medvedev is a Russian politician and former president of the Russian Federation.

137 Leonid Kuchma is a Ukrainian politician who served as president of Ukraine (19942005). See: http://news.bbc.co.uk/1/hi/world/europe/2283925.stm (access: 9.12.2016); T. Kuzio, Ukraine Under Kuchma...

138 The Association Agreement is a bilateral agreement between the European Union and non-member states that want to have greater integration with the EU. For more information about Ukraine's failure to sign the EU Association Agreement see: http://www.globalsecurity.org/military/world/ukraine/azarov.htm and https:// jamestown.org/program/failure-to-sign-association-agreement-with-eu-triggers-violence-in-ukrainian-capital/ (access: 17.12.2016).

139 Petro Poroshenko is a Ukrainian politician and oligarch. He is the fifth and current President of Ukraine (from 2014). See: http://www.president.gov.ua/en/president/petro-poroshenko, http://www.bbc.com/news/world-europe-26822741 (access: 23.12.2016). 
for that. At least there is a certain tradition. I think that if we have this path of dependence, it includes not only the decades of this passivity, or slavery even, or Stalinist repressions, but also some periods of freedom explosions. And here we have had these two Maidans, or this student Revolution on Granite, but also all these other histories of fighting for independence. Yes. It is not an accident that these people at the Maidan were making references to Cossack sich ${ }^{140}$. This is important because it points to independence, to these freedoms. Yes... Even this reference, I know it is very unpleasant for the Poles, or people in the West, to the UPA tradition ${ }^{141}$. OK; I am not a supporter of it, but we also need to know how it is perceived. It is perceived in a completely different way than it was historically. Meaning the accents are put on completely different features, on this sacrifice, on this patriotism, on this fighting, meaning this hopeless fighting with a stronger opponent. I think that has already been quite deeply internalized by society. Even the sole fact that these slogans have been accepted, they have not been imposed by the authorities, this "Ukrainu Slava"142 and slava to the heroes, they became popular at the grass root level and accepted and at the same time this death to enemies was rejected. This is also interesting how this collective thinking works. Spontaneously, but also in a limited way rejects what is not acceptable: what is - how to say - anachronistic, unnecessary - the third part of this slogan. "Slava Ukrainu, glory to the heroes, death to the enemies". There is no death to the enemies. So it is ok. I think it points to a healthy social core.

IR: Thank you very much.

140 S. Plokhy, op. cit., p. 12.

${ }_{141}$ UPA is the abbreviation for the Ukrainian Insurgent Army which was the Ukrainian nationalist organisation which was active in the period of 1942-1949. See: D. Marples, Heroes and Villains. Creating National History in Contemporary Ukraine, Budapest 2007; G. Kasianov, P. Ther, A Laboratory of Transnational History. Ukraine and Recent Ukrainian Historiography, Budapest 2009.

${ }_{142}$ "Ukrainu Slava", which means "Glory to Ukraine" was a slogan used during the times of the Ukrainian Insurgent Army, but also during the recent Euromaidan as well. See: http://euromaidanpress.com/2016/o6/13/a-short-history-of-the-ukrainian-greetingslava-ukrayini/ (access: 24.12.2016). 
Interview with Maria Tomak ${ }^{143}$

Katerina Novikova: What are the most important stages of your life that have formed your position? Some events, meetings or books?

Maria Tomak: I was born in 1987 in Kyiv. I grew up here, studied in school, then in high school and then at the Faculty of Journalism at the Taras Shevchenko University ${ }^{144}$. During my studies I started to work. Initially, in the "glamorous" press [laughs] and then I got a job at the newspaper "Аень" ("The Day") ${ }^{145}$. I worked there for almost six years, starting with the position of a correspondent and up to the deputy chief editor. A few months before the Maidan ${ }^{146}$, I left the newspaper and started to work in the field of human rights protection, in the NGO "Center for Protection of Civil Liberties"147. And with this organization I became a participant of the Maidan and the initiative "EuromaidanSOS"148.

It was a turning point in my life. For one month now, I no longer work for the "Center for Protection of Civil Liberties" since we began a new project,

143 The interview with Maria Tomak took place on 18 August 2016. The Interview was conducted and transcribed by Katerina Novikova and translated by Yulia Oreshina.

144 The Kyiv National Taras Shevchenko University is a leading and one of the oldest universities of Ukraine. The University is known for its journalism program. See: http://www.univ.kiev.ua/en/ and http://journ.univ.kiev.ua/node/563 (access: 12.12.2016).

145 The newspaper "The Day" is a daily Ukrainian-wide newspaper on socio-political issues. See: https://day.kyiv.ua/ru (access: 12.12.2016).

146 In this context, the Maidan refers to the Euromaidan Revolution, also known as the Revolution of Dignity - the events which took place in Ukraine between November 2013 and February 2014. As a result of the events, President Viktor Yanukovych fled the country and new elections took place in May 2014. See http://euromaidanpress.com/2016/o2/19/a-timeline-of-the-euromaidan-revolution/\#arvlbdata (access: 12.12.2016) and E. Burgsdorff, op. cit. and Ukraine's Euromaidan...

147 The NGO "Center for Protection of Civil Liberties" was founded in 2007, with the aim to protect and promote human rights values in Ukraine. For more information see http://ccl.org.ua/pro-nas/ (access: 13.12.2016).

${ }_{148}$ EuromaidanSOS is a volunteer initiative which was set up during the Euromaidan to assist victims with legal advice and operative aid. See: https://euromaidansos.org/ (access: 13.12.2016). 

and journalist activities. In my opinion, these two spheres do not contradict one another and especially in Ukraine, they organically complement one another. Well, I started to deal with the issues of political persecution already during the time of the Euromaidan. First of all, we are talking about political persecution within the frames of the Russian-Ukrainian war ${ }^{150}$. It's about Ukrainian political prisoners in Russia and in occupied Crimea, and in addition I am engaged in topics of the East, the $\mathrm{ATO}^{151}$ zone, and the liberated territories where contradictory processes are taking place. These are the decisive issues for us today.

I was a participant of the Orange Revolution ${ }^{152}$ when I was 17 years old. Then, as a natural sequel, I participated in the Euromaidan. I believe that the Maidan was a Euromaidan from the beginning until the end - it was a struggle for Europe in a broad sense. After all, there is such an interpretation that the Maidan was a Euromaidan before 30 November ${ }^{153}$, and then it turned into the Maidan. I categorically disagree with this because it seems that people perceive these events too narrowly. Sometimes you hear questions: why does Ukraine need Europe, since there is a crisis there? It is like saying, your dad is an alcoholic, so you renounce him. Of course, there are

149 The project "Media Initiative for Human Rights" aims to build better awareness in the media of human rights violations and support victims of human rights abuse. See: https://youcontrol.com.ua/catalog/company_details/40750793/ and https:// www.facebook.com/MediaInitiativeForHumanRights/ (access: 16.12.2016).

150 In this context the "Russian-Ukrainian War" refers to the conflict taking place in Eastern Ukraine between government forces and rebel separatists who are being supported by the Russian Federation. See: http://www.bbc.com/news/world-middle-east-26248275 (access: 12.12.2016).

151 ATO stands for "Anti-Terrorist Operation". It is the official name for Ukraine's military operations against the separatist forces in the country's east, also known as the zone of conflict (or ATO zone). See: http://112.ua/ato/karta-ato-po-sostoyaniyu-na-27-yanvarya-368041.html (access: 14.12.2016).

152 The Orange Revolution is the popular name for the political events that took place in Kyiv in 2004/2005 following the falsification of the results of the presidential elections. See: V. Paniotto, op. cit.; M. Beissinger, op. cit.; https://www.wilsoncenter.org/ article/the-orange-revolution-and-the-maidan-parliament (access: 23.12.2016).

15330 November 2016 refers to the events which took place on the Maidan Square in Kyiv when Berkut special police forces cracked down on the peaceful protesters injuring 79 people. See: http://www.bbc.com/news/world-europe-25164990 (access: 27.03.2017). 
392 disadvantages. However, Ukraine is a part of Europe. Those who say that often don't understand Russia and its authoritarian traditions.

$\mathrm{KN}$ : Europe is a value system. It seems that at the Euromaidan it was not so much about joining the EU or creating a similar structure. For Europeans it was a shock that in Ukraine those values were considered very seriously...

MT: Yes, exactly, and I really liked the phrase, I think it was Oxana Pachlovska ${ }^{154}$ or someone else from the thinkers who said, Ukraine was more European than Europe itself. However, the sphere in which I now work gives me a lot of sobriety. Before, I had a tendency to generalize everything. And when you work with criminal cases of specific people you begin to look at things more realistically. We generally say the "Maidan", but in reality different forces were acting on the Maidan, sometimes very contradictory people and so-called agents ${ }^{155}$. For example Krasnov ${ }^{156}$ who is currently accused of collaborating with the administration ${ }^{157}$ and Russia.

$\mathrm{KN}$ : He was detained recently...

MT: Yes, and by the way, he was very active at the Maidan, in particular he acted during the take down of the Lenin monument ${ }^{158}$. I welcomed this back then, because if there is no museum, let it be at least in such a manner. If there is no evolution, a revolution appears... So, despite the fact that negative aspects affect the general picture, it still remains unchanged. I have seen the evolution of my parents who were completely Soviet people for

154 Oxana Pachlovska is a professor of Ukrainian language and literature at La Sapienza. See: http://www.lettere.uniroma1.it/en/users/oxana-pachlovska (access: 14.12.2016).

155 E. Burgsdorff, op. cit., p. 1.

156 Stanislav Krasnov was head of the Head of the Civil Corps "Azov-Crimea", a paramilitary organization. He has been accused of treason by Ukrainian authorities, suspected of working with Russian intelligence. See: http://politrada.com/dossier/ Stanislav-Aleksandrovich-Krasnov/ (access: 14.12.2016).

157 Reference to Viktor Yanukovych See https://www.britannica.com/biography/Viktor-Yanukovych (access: 16.12.2016).

158 The Lenin Monument in Kyiv stood on Taras Shevchenko Boulevard. It was taken down by protesters on 8 December 2013. See: http://www.pravda.com.ua/news/2013 /12/8/7005453/ (access: 15.12.2016). 
whom pro-Ukrainian and pro-European rhetoric was completely alien. As they say - quilted jackets. [laughs] Nevertheless, a full evolution happened to them - they were constantly at the Euromaidan, of course under my influence. They actively participated in the creation of the common good; they were delivering goods and products etc., so they participated in civil society. And later, of course, they supported the army. With the example of such people, I see that despite all these provocateurs, a huge breakthrough in the public consciousness has taken place.

KN: Your parents were not demonstrating at the times of the Granite Revolution $^{159}$ and the revival of national processes?

MT: Well, they did nothing special then, but during the Orange Revolution they were sceptical and did not let me out of the house, believing that it could be dangerous. I had to escape from home. They didn't think that you can make an impact in such a way, and they also didn't have that sense of community which we found here at the Euromaidan. Of course, from 2004 until 2014 I also experienced a certain evolution. During this time I was conducting conversations with my parents and it worked. The Euromaidan was the first experience of the civil society and the awareness of the existence of common values for them. Even though my parents were not ardent Soviet sympathizers after the collapse of the USSR ${ }^{160}$, they didn't trust the system, but they were not doing anything to express their opinions. It seems however, that many people were like this.

KN: So, what was so special about the Euromaidan that it made so many people come out of their homes?

159 The Revolution on Granite was the hunger strike organized by Ukrainian students in Kyiv in October 1991. For more see: http://mfa.gov.ua/en/news-feeds/foreign-offices-news/41110-25-ta-richnicya-studentsykoji-revolyuciji-na-graniti, http://www.istpravda.com.ua/articles/2015/10/2/148579/ and http:/gazeta.dt.ua/socium/pershiy-maydan-25-rokiv-revolyuciyi-na-graniti-_.html (access: 20.12.2016).

160 The Union of Soviet Socialist Republics (USSR) existed between the 1922 and 1991 and was made up of 15 republics, including the Ukrainian Soviet Socialist Republic. More on the collapse of the USSR see: H. Carrère d'Encausse, Decline of an Empire: the Soviet Socialist Republics in Revolt, New York 1979. 
394 MT: It seems to me that there were a few origins. First, it is the Magdeburg Rights $^{161}$ and the historical traditions and experience of governance, which is stored somewhere in our shared memory. Second, a specific situation: the violence served as the trigger, and there we see a fundamental difference with Russia. Let's compare two events. On 30 November 2013, the attack on students took place in Kyiv; and the Bolotnaya Square protests in Moscow ${ }^{162}$, after the suppression of which nobody came out. In Ukraine, the reaction was fundamentally converse - angry people massively came to the Maidan. Many people started to believe in the European project for Ukraine. And even today they believe in it, though maybe not all of them. But at that moment, it was understood that this project is important.

For example, many people all of a sudden turned out to be supporters of Europe. There is an interesting story. When the Anti-Terrorist Operation had already started, Sloviansk ${ }^{163}$, Krasnyi Lyman ${ }^{164}$ were liberated, one of the Easterners who was an entrepreneur shared his thoughts with me, that the main promoter of Europe for him was actually Yanukovych. Even though he was always hesitating, the rhetoric of the party was filled with European slogans. In this way, they ${ }^{165}$ managed to convince their electorate to Europe.

161 Magdeburg Rights (or Law) refers to the decree by Otto I of the Holy Roman Empire, later adopted during the 13th and 14th centuries as the basis for German town laws. The rights gave significant autonomy to many cities and towns in Central and Eastern Europe, including Ukraine see: http://istznu.org/dc/file.php?host_id=1\&path=/page/ issues/20/20/vinarchuk.pdf and http://www.wumag.kiev.ua/wumag_old/archiv/ 2_99/magdeburg.htm (access: 16.12.2016).

162 The Bolotnaya Square protests took place on 6 May 2012 in Moscow Russia. As a result over 30 people were arrested and prosecuted. See: http://www.aif.ru/society/29817, http://www.forbes.ru/sobytiya/lyudi/77323-miting-10-dekabrya-na-bolotnoi-ploshchadi-vse-podrobnosti and http://www.ntv.ru/video/269206/ (access: 17.12.2016).

163 Sloviansk is a city in eastern Ukraine in the Donetsk oblast. It was a place of heavy fighting between government forces and rebel separatists between April-July 2014. Ukrainian forces retook the city on 5 July 2014. See: http://mashable.com/2014/07/05/ pro-kremlin-rebels-flee-ukraine (access: 27.03.2017).

164 Krasnyi Lyman, now called Lyman, is a city in eastern Ukraine in the Donetsk oblast and was the scene of heavy fighting between government and separatist forces. See: http://en.censor.net.ua/news/290554/in_krasnyi_lyman_the_ato_forces_continue_ fighting_militants_refused_to_surrender (access: 27.03.2017).

165 Reference is made to Viktor Yanukovych and his administration. 
So, the main ideas at the Maidan were a European project of Ukraine and the rejection of violence. These are both the November 30 and the socalled dictatorial laws from 16 January $2014^{166}$. Do you remember how it was back then, when everyone started to walk with pots on their heads, creating sort of a performance? There was a festive atmosphere. Actually, quite similarly to the Orange Revolution, there was a great deal of creativity. Many memes ${ }^{167}$ were created. In this context, it is worth mentioning how Facebook became a huge factor. The initiative the "Euromaidan SOS" would not have been possible without Facebook since it is a huge mobilizing resource. It worked until the beginning of the military aggression in Crimea ${ }^{168}$ and in the East, and among others it is through Facebook that the necessary volunteers were gathered. Currently there is a certain drain of attention, but I'm sure that in case of an aggravation of the situation it can easily become active again.

KN: Indeed, social media was greatly mobilizing and uniting, and created the possibility to instantly receive information.

MT: In fact, to a certain extent Facebook made this revolution.

KN: You mentioned the boom of art. Was it a feature of the Euromaidan or was it during the Orange Revolution as well?

166 The dictatorial laws on 16 January 2014 were passed by Ukraine's parliament during the height of the Euromaidan Revolution. The laws, which were hastily passed without debate, among others, created harsh punishments for organizing and participating in public protests. See: http://www.civicsolidarity.org/article/88o/ukraine-brief-legal-analysis-dictatorship-law, http://euromaidanpress.com/2014/01/16/ january-16-2014-verkhovna-rada-of-ukraine-passes-dictatorship-laws/ and http:// www.heritage.org/research/reports/2014/o1/ukraine-s-anti-protest-laws-a-step-backwards-in-time (access: 17.12.2016).

167 Memes refer to online media content, often humorous, which spread rapidly via the internet.

168 The Ukrainian peninsula of Crimea was seized by pro-Russian forces (suspected to be Russian) starting on 27 February 2014, culminating in a referendum to join the Russian Federation on 16 March 2014, which passed with a reported $97 \%$ of the vote. See: R. Geib, Russia's Annexation of Crimea: The Mills of International Law Grind Slowly but They Do Grind, „International Law Studies”, no. 91 (2015), p. 425-449 and http://www.bbc.com/news/world-europe-26609667 (access: 18.12.2016). 
396 MT: I was not an active participant of the Orange Revolution, but rather an ordinary one. However, it seems to me that it was not so brightly expressed back then. After all, that Maidan was not that much civic, in a sense that there were no specific initiatives then, starting with the service (night transports to Kyiv, etc.) and finishing with the attempt to create a political movement. Here, art played a greater role, for example the creation of Art Barbican ${ }^{169}$. It seems that the emergence of new art and their development was a significant factor during that time, because they realized that freedom is essential for creativity. They were a certain independent force at the Maidan.

\section{$\mathrm{KN}$ : And what about religion?}

MT: Here is a watershed moment between Eastern and Western Christianity ${ }^{170}$. At the Euromaidan there was a unification of all confessions for whom the use of violence was unacceptable ${ }^{171}$. I'm really not a churchgoer but it was a purely human and civil dimension for me. As a human rights activist, I had interviewed some clergymen who were in captivity in the DNR and the LNR ${ }^{172}$. They played a big role there, carried out the evacuation of the population and provided assistance. The Ukrainian Orthodox

169 The Art Barbican was an area near the Maidan for artistic and creative expression as well as exhibitions and literary debates. See: http://www.wsj.com/articles/SB10oo14 24052702303603904579491433856069104 (access: 18.12.2016).

170 The reference here is to Eastern Orthodox Christianity and Western Christianity (Catholicism in particular).

171 Religious symbols were very present during the Euromaidan revolution. For more information on the religious aspects see: http://risu.org.ua/article_print. php?id=54779\&name=society_digest\&_lang=ua\&, and http://www.radiosvoboda. org/a/25212456.html (access: 17.12.2016).

172 DNR and LNR refer to the self-proclaimed separatist republics in the east of Ukraine which emerged after the Euromaidan Revolution. The DNR means the Donetsk People's Republic and LNR refers to the Luhansk People's Republic. See: https:// www.crisisgroup.org/europe-central-asia/eastern-europe/ukraine/russia-and-separatists-eastern-ukraine, https://www.osw.waw.pl/en/publikacje/osw-commentary/2015-06-17/war-republics-donbas-one-year-after-outbreak-conflict and http:// www.neweasterneurope.eu/interviews/1235-where-does-ukraine-s-separatism-come-from (access: 17.12.2016). 
Church Moscow Patriarchate was certainly a negative factor ${ }^{173}$. However, some from that part of the church took part in the Maidan.

KN: Yes, because officially they were not allowed to participate and to openly express their opinion.

MT: The Church now is supporting the army, but I feared they would begin to encroach on the civic space. However it didn't happen.

KN: Coming back to the Orange Revolution, what were its reasons and why did you and your friends join it?

MT: When I was 17 years old, I was a freshman at the university. For the three years before that, I studied at the Ukrainian Humanities Lyceum ${ }^{174}$, which became a new world for me in the sense that the atmosphere had a civic position, and our teacher was inviting many Soviet-era dissidents. This is how I met Vasyl Ovsiyenko ${ }^{175}$, Sverstyuk ${ }^{176}$ and others. The world then opened for me. Because my parents were not involved in any movement, it was a whole new world for me. I then really became interested and it became a part of my world. Before, I had studied in an ordinary school in the Podolski district ${ }^{177}$ and I remember it as a kind of "rubbish" in terms of the attitude towards people and education. In the lyceum instead were very good teachers, charged with a constructive Ukrainian idea. With a fundamentally different attitude towards the students, they were addressing us with a form of politeness, and perceived as individuals. The Ukrainian

173 Eastern Orthodox in Ukraine is divided into several patriarchates, however the only officially recognized patriarchate of the Eastern Orthodox Church in Ukraine is the Ukrainian Orthodox Church Moscow Patriarchate. See: S. Plokhy, F. Sysyn, Religion and Nation in Modern Ukraine, CIUS Press 2003.

174 A high school in the Pechersk district of Kyiv and established by the Taras Shevchenko National University. See: http://www.uhl-edu.kiev.ua/ (access: 29.03.2017).

175 Vasyl Ovsiyenko was a former Soviet dissident and human rights activist. He was arrested and imprisoned many times between in 1973 and 1990. See: http://olexa.org. ua/ukr/persons/v_ovsienko.htm_(access: 29.03.2017).

176 Yevhen Sverstyuk was a civil activist in Ukraine during the Soviet times. He was arrested and imprisoned in 1972 for nearly 15 years. After 1991, he was President of the Ukrainian PEN Club. See: http://1576.ua/people/386o (access: 18.12.2016).

177 A district in the central/north western part of the city of Kyiv. 
national anthem was played daily. However, in my previous school we were also subtlety learning history and the school had national symbols. Nonetheless, the difference between the school and the lyceum was huge. In the lyceum there were teachers who directly participated in dissident circles and who were active cultural figures. A big role was played by my class supervisor; she was inviting us for evenings and poetry readings, especially at the "Teacher's House"178, dissidents were coming to school, she was constantly bringing articles from the "Mirror Weekly"179.

This played a huge role in my civic consciousness. That is why I see the importance of a school education. Above all, civic education, not a patriotic one, is important. Children have to be aware that they are the future citizens, what this means, and what rights they have. That's why this lyceum played a key role in my upbringing. Then I entered into the university. When I was 19 years old, I began to work at the newspaper "The Day" and I had access to famous historians and the possibility to communicate with them, as well as with intellectuals such as Oxana Pachlovska. After all, this newspaper pays great attention to history.

I had reconsidered Russia already at that time, and that is why the current Russian aggression was no surprise for me. Actually, a few months before the attack I was discussing with a friend what would happen if a war starts... The Orange Revolution also influenced me, but at that time I joined neither student nor civic groups. We just went to the Maidan together with other students.

\section{$\mathrm{KN}$ : What motivated you to get involved in those events?}

MT: I remember that there was a falsification in the second round ${ }^{180}$. I don't know where it came to me from. We announced a boycott with our whole

178 The Teacher's House is a historical building located in Kyiv. It is the scene of cultural events and is administered by the Ukrainian Trade Union of workers of Education and Science. See: http://www.museumtrove.com/museum/110616045663247/ Teacher's+House (access: 25.03.2017).

179 The „Mirror Weekly” is one of Ukraine's most influential analytical newspapers published weekly in Kyiv. See: http://mw.ua/ (access: 18.12.2016).

180 Reference to the falsification of the 2004 presidential elections in Ukraine which was the main reason for the outbreak of the Orange Revolution. See: Aspects of the Orange Revolution: Democratization and Elections in Post-Communist Ukraine, ed. by P. D’Anieri, T. Kuzio, New York 2007. 
in the front rows, but I don't remember who proclaimed this. The management of the Institute approached our protest with an understanding at that time. I had a sceptical attitude towards my university and I don't believe that there was a high-quality education there, but the people there were civically oriented. Certainly the odious figure of Yanukovych played a role, together with youthful romanticism, as well as the feeling that you are being fooled which was not normal. Now I realize that even though it was a campaign professionally built by Yushchenko ${ }^{181}$, all these scarves provided on time, proper slogans and a certain narrative which also played its role.

Still, despite these minuses, even though someone took advantage of this, were it political forces or even Russia, you cannot deny the Maidan itself. The events of February 2 oth $^{182}$ have not been investigated, who those snipers were and Berkut ${ }^{183}$. Where did they come from?

KN: Indeed, who led people to protest before the parliament on February 18, who then set up the fire on trucks which were blocking access together with the officials of internal troops?

MT: In fact, this was done by provocateurs. For example, Krasnov was the deputy commandant of the Kyiv City State Administration on the Maidan. He had a great influence in these circles. The world was amazed with the phenomenon of the Euromaidan, not with the destroyed shops and the raked

181 Viktor Yushchenko is a Ukrainian politician who served as president of Ukraine (2005-2010) following a repeated second round of elections in 2005. See: https:// www.britannica.com/biography/Viktor-Yushchenko (access: 16.12.2016).

182 The events of 20 February 2014 refer to the violent clashes where pro-government forces opened fire on protesters. As a result 49 people were shot dead. See: http:// www.bbc.com/news/magazine-31359021. No full investigation of the shooting was ever conducted. See: http://euromaidanpress.com/2016/o2/20/separating-myth-from-reality-6-facts-on-the-shooting-of-the-euromaidan-protesters/\#arvlbdata (access: 17.12.2016).

183 Berkut was a group of Special Police Force managed by the Ukrainian Ministry of the Interior. See: http://www.euronews.com/2014/o2/26/ukraine-berkut-riot-police-to-be-disbanded (access: 8.12.2016). 
400 Lobanovskyi's monument at "Dynamo" stadium ${ }^{184}$. This indicates certain aristocratism of the protest.

$\mathrm{KN}$ : How do you assess the self-organization of the Euromaidan?

MT: In fact the difference between the Orange Maidan and the Euromaidan consisted of dozens of civic initiatives. "Euromaidan SOS" was one of them, the first one. During the Orange Revolution everything was more centralized. Even though we as students were together, we were just coming to the Maidan. The Euromaidan was about self-organization, in the absence of a leader and of non-accepting of politically imposed leaders, neither Klitschko ${ }^{185}$ nor Yatsenyuk ${ }^{186}$, nor the released Yulia ${ }^{187}$. However, the current situation in the country shows that there is a lack of resources for the new forces.

$\mathrm{KN}$ : Were there yet any real changes in the country after the Euromaidan, what are the advantages that you see or do you feel disappointment?

MT: The disappointment with both the Orange Maidan and the Euromaidan is inherent to those who are focused on the model of leadership. Although, at one time I also belonged to those who believed that Yushchenko

184 The Dynamo stadium was the main front in Kyiv which had protesters on one side and government Berkut forces on the other. See: http://www.fcdynamo.kiev.ua/en/ club/stadium/tour/ (access: 15.12.2016).

185 Vitali Klitschko is a Ukrainian politician and current mayor of the city of Kyiv. He made his name as a professional boxing champion and later entered politics by establishing a new party "Udar" and was elected into parliament in 2012. During the Euromaidan he was one of the leading opposition politicians. See: https:/www.theguardian.com/sport/ blog/2014/mar/15/vitali-klitschko-ukraine-sport-politics (access: 18.12.2016).

186 Arseniy Yatsenyuk is a Ukrainian politician who served as prime minister between February 2014 and April 2016. During the Euromaidan he was one of the leading opposition politicians. See: http://www.bbc.com/news/world-europe-36010511_(access: 29.03.2017).

187 Reference to Yulia Tymoshenko - a Ukrainian politician and former prime minister (2007-2010). She was imprisoned in October 2011 for abuse of power under the Yanukovych presidency and released only after Yanukovych fled Ukraine in February 2014. See: http://www.aljazeera.com/indepth/2014/05/profile-yulia-tymoshenko-201452373836833511.html (access: 27.03.2017). 
is a better president. I was against the State which wants to take away a piece of freedom. A protest against the State machine which encroaches on your constitutional civil rights.

KN: In other words, this is a shift of Soviet people who no longer hide, but do something. But is the protest a good way for a real change?

MT: For me, my parents became a small experimental Maidan. It is one thing to go out for the revolution, and the other is to practice your civil duties on a daily basis - to control the power on a local level. Not to give bribes. Voting, based on your conscious, in elections, reading electoral programs, etc. That's why I believe that we need civic education, not a patriotic one that says that the Ukrainian nation is the best, but as a post-traumatic Soviet society that needs to be taught about human rights. I especially realized that when I started working in the area of human rights. Our society doesn't have the basic knowledge about its rights and opportunities. We can create a civil organization or a union, a local community and expect employees to perform their duties. People do not know how to use these tools, and it is profitable for the political class that people will understand that.

$\mathrm{KN}$ : We say that Ukraine is corrupt and ruled by the oligarchs ${ }^{188}$. In other words, nothing has changed? But what is this corruption, does it apply only to the sphere of power?

MT: Corruption is a complex phenomenon. My main discovery of the last year: major statesmen do not come from intelligence or law enforcement agencies, but are such human rights activists like me. In fact we have no state as such. People who work in state institutions are protégés of the oligarchs and their servants. State institutions don't work for the interests of the state; they work for the benefit of the oligarchs. In Western Europe, many people don't understand that. I often speak with representatives of non-governmental structures from Western European

188 See: S. Matuszak, The Oligarchic Democracy: The Influence of Business Groups on Ukrainian Politics, "OSW", no. 42 (2012), p. 1-113; http://carnegieeurope.eu/ strategiceurope/?fa=59798 and http://voxukraine.org/2017/o1/19/oligarchs-more-a-symptom-en/ (access: 17.12.2016). 
states; there the main task of civic organizations is to build the state, not to fight with it, with the officials and what they are doing in their countries. Here we have a very fine line. We just have to perform the state functions instead of the services - municipal, police, etc.

$\mathrm{KN}$ : In other words, your job is to fill in the gaps, like emergency services for the institutions and services that don't work?

MT: Of course, although you should fight with the office holders as well, for example, the demand of the removal of the prosecutor Shokin ${ }^{189}$. However it's very difficult and here is the fine line where the fight is going on and where destabilization has already begun. Each time you have to discern a particular situation. I have seen how certain officials were removed; of course it was in the interest of certain individuals and not the society. It is often a political mechanism, but with the use of civic rhetoric and civic organizations' members. For many high officials, the necessity of defending state interests seems ridiculous. Since the Euromaidan, I have been feeling this lack of understanding. There is a complex system of mutual relationships between the society and the authorities. Here we have the example of Kolomoyskyi ${ }^{190}$, who has gained the image of a patriot with his support of battalions and becoming the governor of Dnipropetrovsk region.

Many believe that Ukraine persists thanks to the compromise of the oligarchs because this is the guarantee of the survival of the state and it's not recommended to break the balance between them. Perhaps there is some truth in it, and this creates the situation which is not black and white but more complicated. First and foremost, it is important to practice being a citizen every day which is not easy at all. My father was in the hospital, and I was forced to give a bribe to the doctor and nurse. Therefore, the issue of corruption has several levels. The money to a nurse's pocket and enormous money laundering at a high level. There is also a developed system

189 Viktor Shokin was the General Prosecutor of Ukraine between 2015 and 2016 who was accused of not doing enough to fight corruption. See: http://file.liga.net/ person/77481-shokin-viktor.html (access: 18.12.2016).

190 Ihor Kolomoysky is a Ukrainian oligarch and former governor of Dnipropetrovsk region (2014-2015). See: http://www.wsj.com/articles/ukraines-secret-weapon-feisty-oligarch-ihor-kolomoisky-1403886665 and http://forbes.net.ua/ua/persons/410-kolomojskij-igor-valerijovich (access: 19.12.2016). 
of pressure over private entrepreneurs, who are forced to nurture the corruption system and impunity of justice at a local level. Impunity destroys our country. People have no immunity against humiliation. People regard the struggle as something ineffective and romantic. There is distrust to the fight against corruption, it is just a game; it doesn't exist in reality.

$\mathrm{KN}$ : Were there certain expectations during the Euromaidan to lead the country to a qualitatively new level?

MT: Obviously, there were expectations of change. I personally thought that after the shootings it could not be the same, there has to be change. It's impossible to steal after what happened. But I see that it is possible, and even during war. I have expanded my imagination about the bottom line. We need a complete turn in European terms, the fight against corruption as a model of state functioning. However, at the Maidan back then, many didn't understand the oligarchic structure of the state and the fact that the officials are hired managers of the oligarchs, not of the society. To get rid of corruption and impunity - these were the greatest expectations of the Maidan.

KN: How do you evaluate the reaction of Europe and America? It seems that abroad, many realized that Ukraine exists.

MT: During the Orange Revolution, I didn't follow the global response. But I see that there was positive feedback to the ability to resist totalitarianism. Of course, during the Euromaidan there was the relentless attention of foreign media, particularly with regard to civic initiatives and groups. The representatives of foreign mass media, even from Al Jazeera ${ }^{191}$, were constantly coming to us, to the "Euromaidan SOS".

The difference between the two revolutions is that during the Orange one, Yushchenko was at the centre of attention, and during the Revolution of Dignity the people themselves were at the centre - those who were making the Euromaidan. I think the attention to Ukraine after that was linked to the war, and now there is a fatigue with Ukraine - this is palpable in conversations

191 Al Jazeera is an international state-funded English-language news and current affairs TV channel owned and operated by Al Jazeera Media Network which is headquartered in Doha, Qatar. See: http://www.aljazeera.com/aboutus/ (access: 18.12.2016). 
404 with MEPs and journalists. However, at the same time the understanding of the importance of Ukraine for Europe is increasing. There is a popular expression currently: "the canning was broken", that is the "mole holes" of Russia in Europe were opened, its lobbying, media projects, etc. that influence the public opinion, the politics abroad. Many are shocked, although Russia was influential during the Maidan as well, emphasizing the presence of fascists on the Maidan.

$\mathrm{KN}$ : Many Western leaders were coming to the Maidan ${ }^{192}$. What role did they play in your opinion?

MT: A positive role. Some were taking a risk, since their presence on the Maidan could be interpreted differently and the events could have been distorted.

$\mathrm{KN}$ : Which crucial and symbolic moments of the Maidan do you recall?

MT: Several events were crucial for me. On November 30 and on December 1st, the protest at Bankova Street (I was engaged in it and was going to the courts), the attempt of clearing the Maidan in December with Berkut, the dictatorial laws in January; the so-called baptism by fire at Hrushevsky ${ }^{193}$. After the first killings on the Maidan, the authorities had lost their legitimacy. Nevertheless, the Maidan was positioning itself as peaceful. It's surprising though that violence hadn't started before.

When the Molotov cocktails were first used, it seemed to me that this was all done by the provocateurs. But then I saw who was taken to the emergency room with burns and wounds (I was buying medicine at the pharmacy and bringing it to them). I saw that they were not radicals but ordinary people. I personally didn't take part in mixing cocktails but I felt myself to be a part of that protest. As someone wrote on Facebook back then, when someone is

192 For more information on Western leaders' visits to Maidan see: http://www.cbsnews. com/news/us-victoria-nuland-wades-into-ukraine-turmoil-over-yanukovich/ and https://www.theguardian.com/world/2013/dec/15/john-mccain-ukraine-protests-support-just-cause (access: 19.12.2016).

193 Throughout January and February 2014 Hrushevsky Street in Kyiv became one of the main points of violent clashes between the Berkut and protesters. 
entering a cafe with a bat, you realize that this is a decent person. The next turning point was on February $20^{194}$.

KN: Please, tell more about "Euromaidan SOS", share the experience of the organization and work.

MT: As I have already mentioned, a few months before the Maidan I came to work in a human rights organization called "Center for Civil Liberties", which was actually carrying out the coordination of "Euromaidan SOS". First of all, when Azarov ${ }^{195}$ signed the document, refusing to sign the EU Association Agreement ${ }^{196}$, we hung an EU flag at our organization as a sign of protest. I was present at the protest on November $22^{197}$, which was called by Mustafa Nayyem ${ }^{198}$. And the "Euromaidan SOS" itself was created after the attack on November $30^{199}$. The initiative to organize it belonged to my colleague Alexandra Matviychuk ${ }^{200}$. She is more orderly and rational and I'm very emotional. She maintained that we should not panic but systematically work with the violence.

We started to make lists of those who disappeared, opened a hot line and a page on Facebook. The scale was rapidly growing; every hour was bringing hundreds of new followers. The response to the irrational use of

194 Reference to 20 February 2004.

195 Mykola Azarov was the prime minister of Ukraine during the Yanukovych presidency between 2010 and 2014.

196 The Association Agreement is a bilateral agreement between the European Union and non-member states that want to have greater integration with the EU. For more information about Ukraine's failure to sign the EU Association Agreement in 2013 see: http://www.globalsecurity.org/military/world/ukraine/azarov.htm and https:// jamestown.org/program/failure-to-sign-association-agreement-with-eu-triggers-violence-in-ukrainian-capital/ (access: 17.12.2016).

197 Reference to demonstrations on 22 November 2003.

198 Mustafa Nayyem is a Ukrainian politician and investigative journalist. His Facebook post on 22 November which called on people to go out to the streets and protest is largely credited as starting the Euromaidan. See: http:/www.globsec.org/globsec2016/panellist/mustafa-nayyem-1 (access: 18.12.2016).

199 Reference to events in Kyiv that took place on 30 November 2003.

200 Alexandra Matviychuk is a human rights activist and chair of the board of the center for civil liberties. See: http://ukropnews24.com/in-russia-hold-more-than-30-citizens-of-ukraine-human-rights-activist/ (access: 29.03.2017). 
406 force was rational and based on the rule of law. It was a link between the victims and the lawyers. A lot of lawyers from all over Ukraine contacted us - after all, let's remember, the Euromaidan was not limited to Kyiv - and expressed their willingness to work, to defend the victims in courts. There was 400 in total in the database.

The hot line worked and the headquarters, an informational entry point of various initiatives, received people with different needs. People were calling, reporting the missing and victims, we were looking for lawyers and they in turn were looking for victims, finding them in detention centres, courts or hospitals. During the events of 19-20 February ${ }^{201}$, our activists already pulled out 20 dead from the Maidan. The relatives of the dead and injured were approaching us, we were helping to make identifications. I led the broadcast from the district and appeal courts of Kyiv, where the courts were holding people as a preventive measure. I kept tracking the number of detainees, from 13 to more than 6o, and on 20 February ${ }^{202}$ in the Obolonskyi district ${ }^{203}$ court there were already hundreds of detainees on the lists. But they were not brought there, and then things became different and they were not considered. In fact there were a lot of directions; I didn't coordinate all of them.

KN: Were foreign journalists interested in what was going on? How did they find you?

MT: It was easy to find us since our initiative was already quite popular. They were curious of how we work, what we were doing, and wanted to see the lists of the victims and advocates. We were repeating what we thought was exceptional about the Euromaidan - it was exactly this rational response to irrational violence. We were not fascists but citizens who remained peaceful and were creating initiatives as ours, working systematically and ensuring an infrastructure. We showed our readiness to fight in the courts for justice, even though a lot of radically-minded Maidan activists were sceptical about this, they didn't believe that the truth can be proved in such a way. First of all,

201 Reference made to events that took place in Kyiv on 19-20 February 2004.

202 Reference made to events that took place in Kyiv on 20 February 2004.

203 One of Kyiv's districts. See: http://visitkyiv.com.ua/en/visiting_city_card/authorities/ 79/obolonskyi-district-state-administration?itypes $=6$ (access: 29.03.2017). 
you should realize that fundamental rights ${ }^{204}$ are important and it is worth defending them in court. And this is the way for changes in the country.

\section{KN: What initiatives has the "Euromaidan SOS" transformed into now?}

MT: The organizations have gone in many different directions, but in general the vast majority continued to work, from helping the army and the Anti-Terrorist Operation. Overall, the "Euromaidan SOS" didn't change its direction of activity. However, individual volunteers joined other projects, including the ATO zone. Oksana Syroyid ${ }^{205}$ reported on the human rights violations after the liberation of Sloviansk. The lawyers of detainees created the Lawyers Advisory Group ${ }^{206}$ - they work with victims and in courts. Thanks to them, several people from Berkut have already been found and detained. I started to deal with the issues of political prisoners, hostages in the DNR and LNR, and the release of Kremlin prisoners. My task is to look at the areas of human rights and journalism. However, without public discourse on the topic, nothing will work. Only talking is not a way out. My work also involves interactions with international organizations, in particular in the area of creating international pressure towards Ukrainian affairs. I'm working with MEPs and with Western media. Already during the Euromaidan, I went to Brussels to explain the situation on the ground. We met Elmar Brok ${ }^{207}$. We went there in February ${ }^{208}$, and on the $17 \mathrm{th}^{209}$ the violence had started. At the same time, an exhibition was launched about the Euromaidan ${ }^{210}$ and everyone wanted to hear the reaction to the tragic events. We urgently changed our tickets to go home, but we managed to get into Brok's press conference. He spoke about the role of Russia which contributed to the escalation of the conflict in Ukraine.

204 Reference to fundamental human rights.

205 Oksana Syroyid is a Ukrainian politician and the deputy speaker of the Ukrainian parliament (2014-present). See: http://samopomich.ua/syroid-oksana/ (access: 15.12.2016).

206 Laywers Advisory Group or Bar Advisory Group is a group of volunteer lawyers set up by EuromaidanSOS to help victims of the Maidan. See: https://www.facebook. com/pg/aap.adg/about/?ref=page_internal (access: 31.03.2017).

207 Elmar Brok is a German Politician and Member of the European Parliament from Germany. See: http://www.eppgroup.eu/mep/Elmar-BROK (access: 18.12.2016).

208 Reference to February 2014.

209 Reference to 17 February 2014.

210 Reference to an exhibition that was presented at the European Parliament. 
$\mathrm{KN}$ : Do you see the continuity of the revolutions?

MT: Yes, and I can see the continuity of revolutions with the historical traditions and with dissident movements as well. However, for most people the comparison with history came only together with the war, in particular the comparison of the Cossacks and the army. The initiative of the Committee of the First of December ${ }^{211}$, where the leading intellectuals of Ukraine had empowered themselves, also had a certain manifestation.

KN: Thank you for our conversation.

MT: Thank you for the opportunity to share.

211 The Committee of the First of December is a group of Ukrainian intellectuals and public figures who aimed to strengthen Ukrainian national identity. See: http://1-12. org.ua/pro-nas (access: 17.12.2016). 


\section{Bibliography}

Åberg M., Paradox of Change: Soviet Modernization and Ethno-Linguistic Differentiation in Lviv, 1945-1989, "Harvard Ukrainian Studies", Vol. 24 (2000), p. 285-301

Aslund A., The Economic Policy of Ukraine after the Orange Revolution, "Eurasian Geography and Economics", no. 5 (46) (2005), p. 327-353

Aspects of the Orange Revolution: Democratization and Elections in Post-Communist Ukraine, ed. by P. D'Anieri, T. Kuzio, New York 2007

Basilevsky A., Early Ukraine: A Military and Social History to the Mid-19th Century, Jefferson 2016

Beacháin D.Ó., Polese A., The Colour Revolutions in the Former Soviet Republics: Successes and Failures, London 2010

Beissinger M., Mechanisms of Maidan: The Structure of Contingency in the Making of the Orange Revolution. "Mobilization: An International Quarterly", no. 1 (16) (2011), p. 25-43

Bosworth M., Memory and the practice of oral history, [in:] Memory and history. Understanding memory as source and subject, ed. by J. Tumblety, Routlege 2013

Burgsdorff E., The Euromaidan Revolution in Ukraine: Stages of the Maidan Movement and Why They Constitute Revolution, "Inquiries Journal", no. 2(7) (2015), p. 1-3

Carrère d'Encausse H., Decline of an Empire: the Soviet Socialist Republics in Revolt, New York 1979

Chirovsky N., Moscow's Russification of Ukraine: Papers and Articles, New York 1987

Collecting and interpreting Qualitative Materials, ed. by N.K. Denzin, Y.S. Lincoln, Sage 2013

Davies N., God's Playground. A History of Poland, Vol. 1: The Origins to 1795, Vol. 2: 1795 to the Present, Oxford 2003

Democratic Revolution in Ukraine: From Kuchmagate to Orange Revolution, ed. by T. Kuzio, New York 2009

Diuk N., Youth as an Agent for Change: The Next Generation in Ukraine, "Demokratizatsiya", no. 2 (21) (2013), p. 179-196

Forbig J., Ukraine after the Orange Revolution, Washington 2005

Fournier A., Mapping Identities: Russian Resistance to Linguistic Ukrainisation in Central and Eastern Ukraine, "Europe-Asia Studies", vol. 54, no. 3 (May, 2002), p. 41-433

Francuz P., Francuz H., W barwach jesieni. Percepcja ekspozycji muzealnej przez osoby starsze, Warszawa 2016, expertise in P. Kowal's archives

Frisch M., A Shared Authorityp. Essays on the Craft and Meaning on Oral and Public History, New York 1990

Geib R., Russia's Annexation of Crimea: The Mills of International Law Grind Slowly but They Do Grind, „International Law Studies”, no. 91 (2015), p. 425-449

Grinczenko G., Historia mówiona na Ukrainie: ludzie, tematy, fakty, „Wrocławski Rocznik Historii Mówionej", no. 3 (2013), p. 73-92 
Haran O., Zolkina M., Ukraine's Long Road to European Integration, "Ponars Eurasia", no. 311 (2014)

Johnson J., Banking in Russia: Shadows of the Past, "Problems of Post-Communism", vol. 43 (3) (1996)

Kasianov G., Ther P., A Laboratory of Transnational History. Ukraine and Recent Ukrainian Historiography, Budapest 2009

Komunizm. Ideologia, system, ludzie, ed. by T. Szarota, Warszawa 2001

Kowal P., Dlaczego doszło do Okragłego Stołu? Przyczyny zmian politycznych w Polsce w latach 1989-199o w opiniach polityków, aktywnych uczestników wydarzeń tego okresu, [in:] Komunizm. Ideologia, system, ludzie, ed. by T. Szarota, Warszawa 2001, p. 156-173

Kowal P., Wapiński M., A Tale of Three Maidans, "New Eastern Europe”, no. 2 (XI) (2014), p. 7-13

Kurkowska-Budzan M., Informator, świadek historii, narrator - kilka watków epistemologicznych i etycznych oral history, „Wrocławski Rocznik Historii Mówionej”, no. 1 (2011), p. 9-34

Kuzio T., Democratic Revolution in Ukraine: From Kuchmagate to Orange Revolution, Oxford 2013

Kuzio T., Ukraine Under Kuchma, Political Reform, Economic Transformation and Security Policy in the Independent Ukraine, London 1997

Lapychak C., Independence: Over 90\% Vote Yes in Referendum; Kravchuk Elected President of Ukraine, "The Ukrainian Weekly", no. 49 (LIX) (1991), p. 1-16

Marples D., Heroes and Villains. Creating National History in Contemporary Ukraine, Budapest 2007

Matuszak S., The Oligarchic Democracy: The Influence of Business Groups on Ukrainian Politics, "OSW", no. 42 (2012), p. 1-113

Maubach F., Świadek historii. Swobodne wspominanie a krytyka źródta historycznego - o ambiwalencji metody w zachodnioniemieckiej oral history okoto roku 1980, „Wrocławski Rocznik Historii Mówionej", no. 3 (2013), p. 39-72

Memory and history. Understanding memory as source and subject, ed. by J. Tumblety, Routlege 2013

Niethammer L., Memory and History, Frankfurt a Main 2012

Onuch O., Mapping Mass Mobilization. Understanding Revolutionary Moments in Argentina and Ukraine, New York 2014

Paniotto V., Ukraine: Presidential Elections 2004 and the Orange Revolution, "Kyiv International Institute of Sociology Report", (2004), p. 1-27

Plokhy S., The Cossacks and Religion in Early Modern Ukraine, Oxford 2001

Plokhy S., Sysyn F., Religion and Nation in Modern Ukraine, CIUS Press 2003

Pritsak O., The First Constitution of Ukraine (5 April 1710), "Harvard Ukrainian Studies", (22/1998), p. 471-496

Pryshchepa K., Once a Protester, Always a Protester, "New Eastern Europe”, no. 1 (XXV) (2017) 
Revolution in Orange: The Origins of Ukraine's Democratic Breakthrough, ed. by A. Aslund,

M. MacFaul, Washington 2006

Romaniuk R., New Tools of the Revolution, "New Eastern Europe", no. 1 (XXV) (2017)

Shapovalova N., The Positions of the Main Ukrainian Stakeholders on the Russia-Georgia Conflict, "SIPU report", no. (2008), p. 1-7

Shopes L., Making Sense of Oral History, History Matters: The U.S. Survey Course on the Web, http://historymatters.gmu.edu/mse/oral.htm

L. Shopes, What Oral History Is, and Isn't, [in:] Collecting and Interpreting Qualitative Materials, ed. by N.K. Denzin, Y.S. Lincoln, Sage 2013

The End of the Soviet Union: Stanislau Shushkevich's Eyewitness Account, "Demokratizatsiya", no. 3 (21) (2013), p. 315-337

The Guns of August 20o8: Russia's War in Georgia, ed. by E. Svante, S. Cornell, F. Starr, New York 2009

Ukraine's Euromaidan: Analyses of a Civil Revolution, ed. by D.R. Marples, F.V. Mills, Stuttgart-Hannover 2015

Wilson A., Ukraine Crisis. What it Means for the West, Yale University Press 2014

Wilson A., Ukraine's Orange Revolution, New Haven 2006 
Iwona Reichardt

Paweł Kowal

Ukraine's path towards democratisation. Interviews with Viktor Yushchenko, Mykola Riabchuk, Maria Tomak
The article introduces the reader to the theoretical and historical framing of the $3 R$ project. Firstly, it takes notice of the fact that in the recent Ukrainian history three important waves of protest happened in the same location: in the Independence Square in Kyiv. Secondly, it outlines the oral history method element in the project presenting the opportunities and possible setbacks of the project's methodology, thus justifying the decision to follow Michael Frish's approach of 'more history'. Finally the authors justify the selection of the three interviews presented in this volume. Most of all, it presents three interviews, with Viktor Yushchenko, Mykola Riabcchuk and Maria Tomak, showing different views on Ukraine's path towards democratisation.

Keywords: oral history, research methods, mass protests, contemporary Ukraine 